\title{
Comprehensive review on repurposing of approved medicine in the management of COVID-19 infection
}

\section{Darshini Patel ${ }^{1}$, Umang Shah $\oplus^{1, *}$, Arya Patel ${ }^{1}$, Sandip Patel ${ }^{2}$, Mehul Patel ${ }^{1}$, Ashish Patel ${ }^{(1}$, Swayamprakash Patel ${ }^{\circ}{ }^{1}$, Nilay Solanki ${ }^{1}$ and Nilesh Pandey ${ }^{3}{ }^{3}$}

\author{
${ }^{I}$ Ramanbhai Patel College of Pharmacy, Charotar University of Science and Technology \\ (CHARUSAT), CHARUSAT campus, Changa 388421, India \\ ${ }^{2}$ Department of Pharmacology, L. M. College of Pharmacy, Ahmedabad, Gujarat, India. \\ ${ }^{3}$ Charotar Institute of Paramedical Sciences, Charotar University of Science and Technology \\ (CHARUSAT), CHARUSAT campus, Changa 388421, India
}

(Received October 28, 2021; Revised December 27, 2021; Accepted December 27, 2021)

\begin{abstract}
The SARS-CoV-2 virus, accountable for the COVID-19 pandemic, is now sweeping the globe. As a result, as this disease resists testing and adoption of new treatments, repositioning existing medications may provide a quick and appealing method with established safety, features, and dose used. They are not, however, specific or focused. However, numerous medications have been studied for their efficacy and safety in treatment of COVID-19, with the majority currently undergoing clinical trials. The goal is to rapidly expand novel preventative and therapeutic medications, as well as to apply preventive methods such as early patient identification, isolation, and treatment. Moreover, reducing transmission through physical contact is also important. In the fight against this dangerous disease, finding the proper treatment is crucial. This article summarizes several anti-malarial, anti-parasitic, monoclonal antibodies, immunosuppressant, and immunomodulating agents in clinical trials for COVID-19. The purpose of this article is to evaluate and explore the potential roles of several medications now utilized in COVID-19.
\end{abstract}

Keywords: COVID-19; SARS-CoV-2; spike protein; drug repurposing; ACE; coronavirus. C2022 ACG Publication. All right reserved.

\section{Introduction}

Wuhan, China's capital and the capital of Hubei province, became the epicenter of aggressive influenza of unknown origin in December 2019 ${ }^{1}$. The virus is SARS-CoV-2, and the causative agent of the infection is coronavirus disease 2019 (COVID-19) ${ }^{2}$. SARS-CoV-2 belongs to the beta coronavirus group, including the previously well-known middle east respiratory illness (MERS) virus ${ }^{3}$. The overall number of reported cases reached 201 million, with over 42,70,000 fatalities by the $7^{\text {th }}$ of August, 2021 ${ }^{2}$. Some surveys have indicated that the incubation time for COVID-19 is 3-7 days after initial contact ${ }^{4}$, 5 . According to the laboratory data, the plasma level of specific pro-inflammatory cytokines such as interleukin-1 beta (IL-1 $\beta$ ), interleukin-8 (IL-8), and tumor necrosis factor-alpha (TNF- $\alpha$ ) increased in severe COVID-19 patients. ${ }^{6}$ COVID-19's subacute and long-term impacts on numerous organ systems are being studied scientifically and clinically ${ }^{7}$. Early studies indicated that SARS-CoV-2 infection might

* Corresponding author: E-Mail: umangshah.ph@gmail.com, Phone: + 91-9537554414; Fax: + 91-2697-265165

The article was published by ACG Publications

http://www.acgpubs.org/journal/organic-communications @ January-March 2022 EISSN:1307-6175

DOI: http://doi.org/10.25135/acg.oc.117.2110.2244

Available online: January 02, 2022 
Repurposing of approved medicine in the management of COVID-19 infection

cause tiredness, chest discomfort, cognitive difficulties, and arthralgia; a decrease in quality of life ${ }^{8-10}$. Coronaviruses have a spherical shape with a diameter of 80-120 nm. Several club-shaped $(17-20 \mathrm{~nm})$ glycoprotein spikes protrude from the surface of the viral envelope ${ }^{11}$. It encodes 16 non-structural proteins (nsp1 - 16), including 4 or 5 structural proteins, as well as the envelope (E), spike (S), membrane $(\mathrm{M})$, nucleocapsid $(\mathrm{N})$, and hemagglutinin (HE) proteins for HCoV-OC43 and HCoV-HKU1 ${ }^{12-15}$. The ACE2-binding affinity for RBD throughout the S1 subunit of SARS-CoV-2 is 10 to 20-fold more significant than in SARS-CoV-1, which may contribute to SARS-increased CoV-2's infectivity and transmissibility. This M glycoprotein appears to be a pre-glycosylated M polypeptide that gives the viral envelope shape and has a size range of $25-30 \mathrm{kDa}$ (221-262 amino acids) ${ }^{16}$. Envelope protein (E) is a small polypeptide with a size range of 8.4-12 kDa that is an integral membrane protein containing 76109 amino acids (Figure 1) ${ }^{11,16}$.

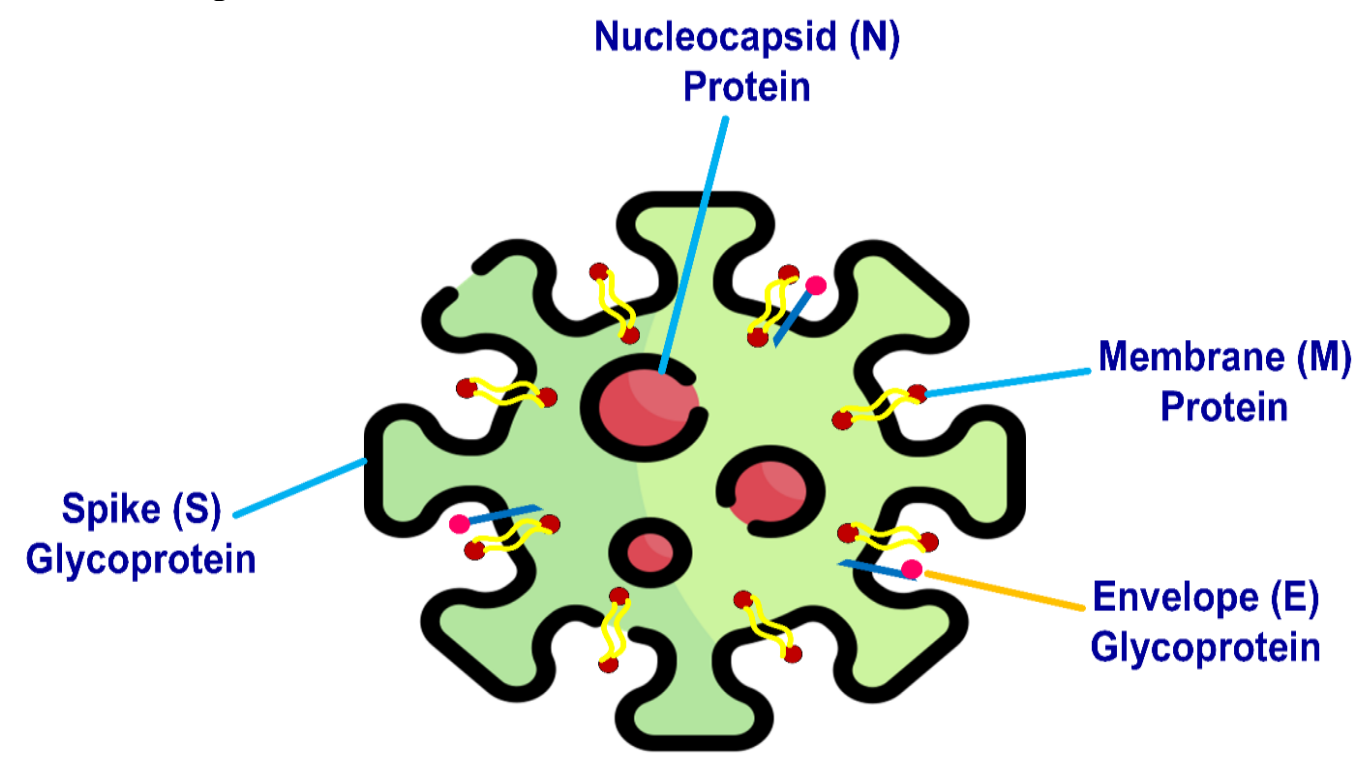

SARS CoV 2 Virus

Figure 1. Structure of COVID-19 virus

COVID-19 virus can affect the whole respiratory tract, amongst the surface of the type-II alveolar cell of lungs are the most impacted. The virus enters into the host cell by ACE-2 receptor ${ }^{17,18}$. Where COVID-19 virus binds to ACE-2 receptor and enters the host cell, it employs a unique surface glycoprotein termed a "spike" ${ }^{19}$. Internalization of the virus causes activation of the nuclear factorkappa B (NF-kB) pathway, which produces a variety of inflammatory factors such as IL-1, IL-17, TNF$\alpha$, and INF- $\gamma^{20-22}$. Increased cytokines also induce the synthesis of endothelium HA-synthase-2 (HAS2 ) in alveolar epithelial cells (type 2) and fibroblasts. ${ }^{23}$. Presence of distinct white patches known as ground glass on computer tomography (CT) images of the lungs in patients suffering from acute respiratory distress syndrome (ARDS) may be due to a large amount of fluid in the lungs ${ }^{24}$. According to the most autopsies, infected lungs are filled with transparent jelly liquid, similar to drowning victims' lungs ${ }^{25}$. HA is linked to ARDS, even though the nature of the clear jelly liquid is unknown ${ }^{26,27}$. In severe and seriously ill hyper inflammation and cytokine storm have been reported, both of which can induce multiple organ failure ${ }^{25}$. Some patients developed rapid progress in combination with acute respiratory distress syndrome (ARDS), systemic inflammatory response syndrome (SIRS), and multiorgan dysfunction syndrome (MODS) due to the presence of ACE-2 receptor in cardiac, renal, and hepatic tissues, which resulted in death in approximately $10 \%$ of patients ${ }^{26,28}$.

Drug repurposing (also known as drug repositioning) is a popular type of drug discovery. It allows authorized medications to treat new ailments, repurposing shelved drugs for additional 
Patel et al., Org. Commun. (2022) 15:1 1-31

indications, and extending patent lifetimes ${ }^{29-31}$. Drug repurposing is a promising field in researching and developing treatments that identify new therapeutic alternatives for existing pharmaceuticals ${ }^{32,33}$. When the safety profiles of the drugs being repurposed have been assessed in the context of drug development for another disease, and even faster when the drugs have been accepted for other diseases and postmarketing safety surveillance data are available, drug repurposing can yield new therapies at a faster rate than novel drug discovery ${ }^{34,35}$. For specific medicines used to treat the present COVID-19 epidemic, pharmacological repurposing has already been recommended ${ }^{36}$. COVID-19 drug repurposing goes through the same three processes as all other drug repurposing initiatives before it can be considered for advancement along the research pipeline; candidate drug identification, mechanistic examination of drug action in preclinical models, and phase II clinical trial review of candidate medications ${ }^{35}$. Two ideas underpin drug repurposing. A single medicine interacts with multiple targets, allowing for new target sites of action for existing molecules ${ }^{37,38}$.

With the sudden surge in COVID-19 cases, there was no time to develop new drugs to work against the SARS-CoV-19 virus. Therefore, various approaches had been investigated to ensure the availability of safe and effective drugs for the treatment of COVID-19 infections. Various research groups investigated several approved drugs with proven safety data against the different molecular targets of the SARS-CoV-19 virus, which produced interruption in the replication of the virus in the body. In the present review, we elaborated on the use of the repurposed drugs to treat COVID-19 infections.

\section{Repurposing of Current Drugs in COVID-19}

\subsection{Chloroquine (CQ) and Hydroxychloroquine (HCQ) - an Anti-malarial Agent}

Quinine, an alkaloid compound classified as quinoline methanol, was isolated from the cinchona tree bark native to south and central America as the first anti-malarial ${ }^{39}$. CQ and HCQ belong to 4aminoquinolines drugs class. HCQ is derived from chloroquine, and the only difference in chemical composition between HCQ and CQ is that HCQ has a hydroxyl substitution at the amine's ethyl group (Figure 2). Because of hydroxyl (-OH) group, HCQ is more soluble. HCQ/CQ was considerably studied and extensively used to prevent and treat malaria for plenty of decades. It is the concept to boom $\mathrm{pH}$ of phagolysosome and, thereby, interrupt virus fusion, and it additionally prevents binding of the virus to cellular floor receptors ${ }^{40}$. CQ was and nevertheless is, used to prevent malaria in pregnancy even though it is no longer powerful in preventing falciparum malaria ${ }^{41-43}$. CQ and its spinoff, HCQ, are medications used to remedy and prevent malaria and autoimmune diseases, including rheumatoid arthritis (RA) and systemic lupus erythematosus (SLE) ${ }^{44}$.

\subsubsection{Role of CQ and HCQ in COVID-19}

Chloroquine and Hydroxychloroquine, anti-malarial medications, have been shown to protect against infections caused by various DNA and RNA viruses, including human coronaviruses ${ }^{45}$. CQ and HCQ are indicated to shorten the span of COVID-19 infection ${ }^{46}$. CQ is the primary drug suggested to have efficacy COVID-1947. Hydroxychloroqine, a more tolerable chloroquine derivative, has also been demonstrated to exhibit the activity against SARS-CoV-2 in-vitro ${ }^{44}$. The activity of CQ and HCQ against SARS-CoV-2 is attributed to prevent entry of virus, inhibiting replication of the virus, or modulating the immune system to withstand against the spreads of virus ${ }^{48}$. The pharmacokinetics of CQ and HCQ is complicated; however comparable ${ }^{49}$. The safety profile of HCQ is better due to less or minimal adverse effects in animals and humans than CQ. CQ and HCQ's pharmacokinetics indicate greater distribution collectively with slow elimination from the body, responsible for causing adverse outcomes of this drug ${ }^{50}$.

In SARS-CoV-2 patients, CQ and HCQ do not have any clinical benefit in disease incidence or development, nor do they provide any substantial proof of expanded critical aspect consequences ${ }^{51}$. CQ primarily inhibits the pre-entry stage of the viral cycle and the transport and post-entry stages of SARS$\mathrm{CoV}-2$ by interfering with viral particles binding to their receptors on the cell surface. It also interferes with glycosylation of the angiotensin-converting enzyme 2 (ACE-2) receptor, raising endosomal $\mathrm{pH}$ and 
Repurposing of approved medicine in the management of COVID-19 infection

preventing SARS-CoV-1 from attaching to target cells. ${ }^{52,53}$. CQ also inhibits cathepsins, implying that it can obstruct SARS-CoV-2 lysosomal acidification, necessitates a low $\mathrm{pH}$ for cleavage of the SARSCoV-2 spike protein, resulting in autophagosome formation. The whole mechanism of CQ and HCQ in SARS-CoV-2 infection is shown in Figure $3^{54,55}$. In THP-1 cells, CQ activates the p38 MAPK by phosphorylating it ${ }^{56}$. Various viruses require this phosphorylation to complete their replication cycles ${ }^{57}$. Inhibition of kinases such as MAPK may have also contributed to the anti-SARS-CoV-2 efficacy ${ }^{52}$. Since the beginning of the current pandemic with COVID-19, a virus linked to SARS, there has been a surge in interest in the potential benefit of CQ and HCQ in treating this infection that is linked to significant morbidity and mortality ${ }^{58}$.

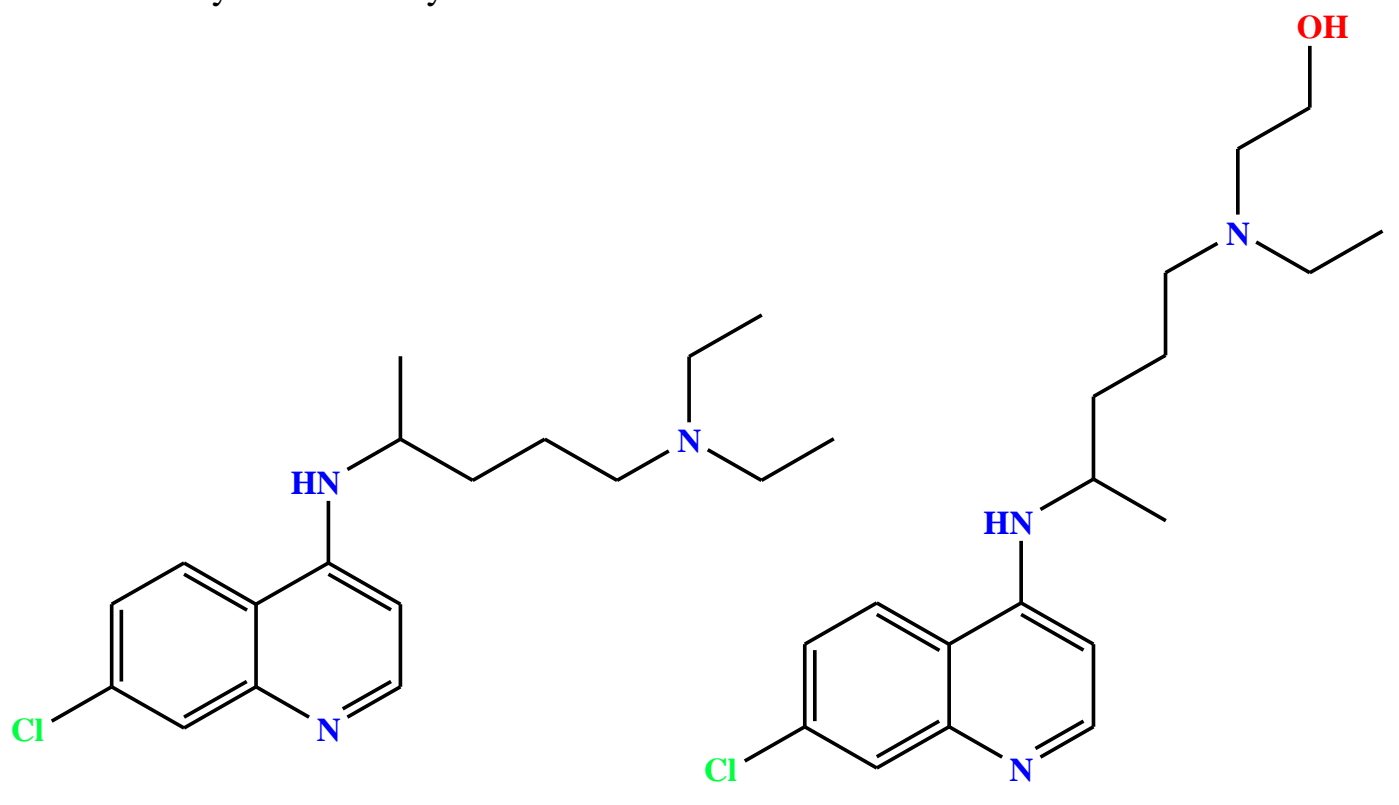

Chloroquine

Hydroxychloroquine

Figure 2. Structure of Chloroquine and Hydroxychloroquine

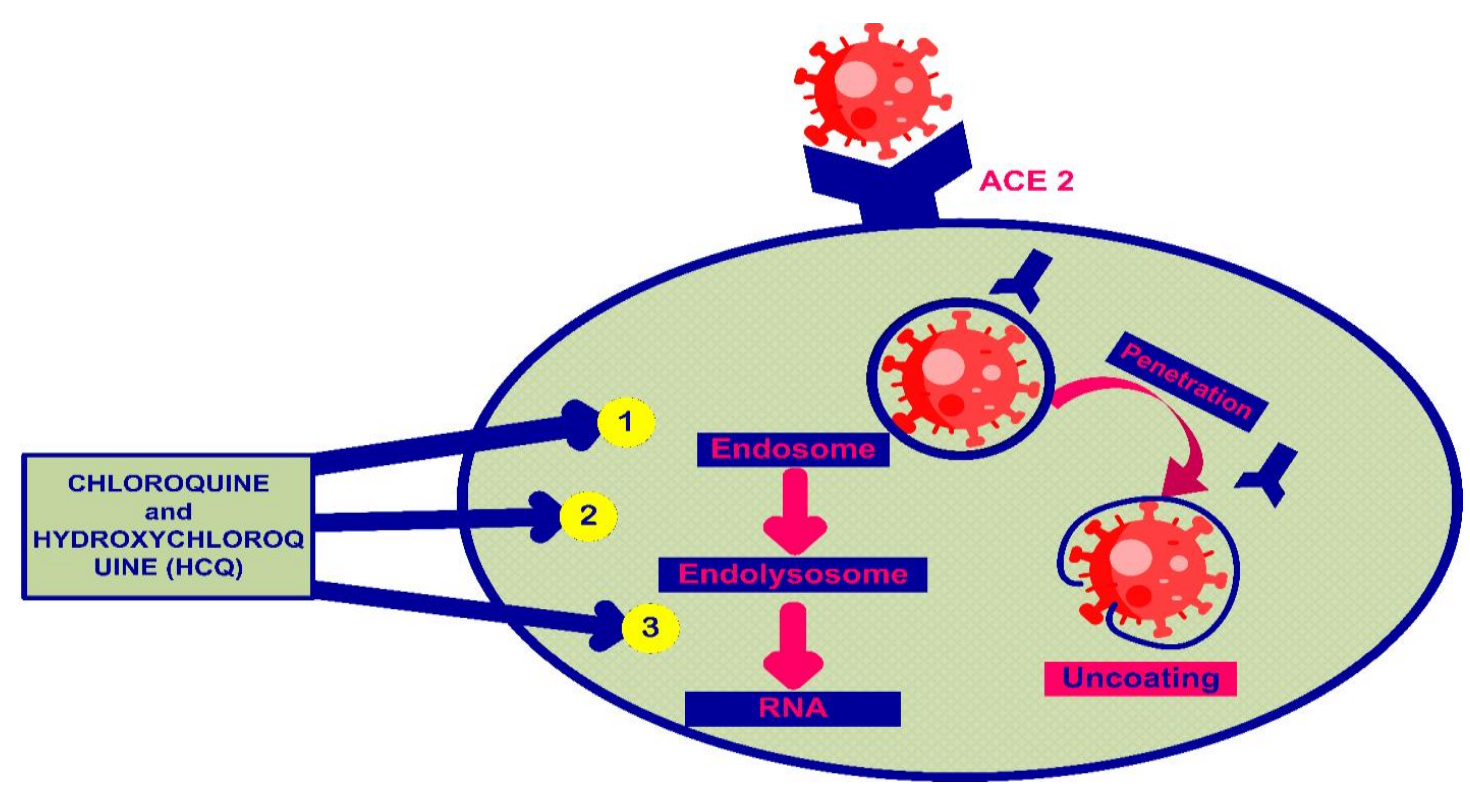

Figure 3. Role of CQ and HCQ in COVID-19 treatment 


\subsection{Azithromycin (AZ) - a Macrolide Antibiotic}

Azithromycin (AZ) (Figure 4) is a macrolide antibiotic with anti-inflammatory and immunomodulatory properties in a variety of respiratory and infectious disorders through modifying innate and adaptive immune responses ${ }^{59,60}$.

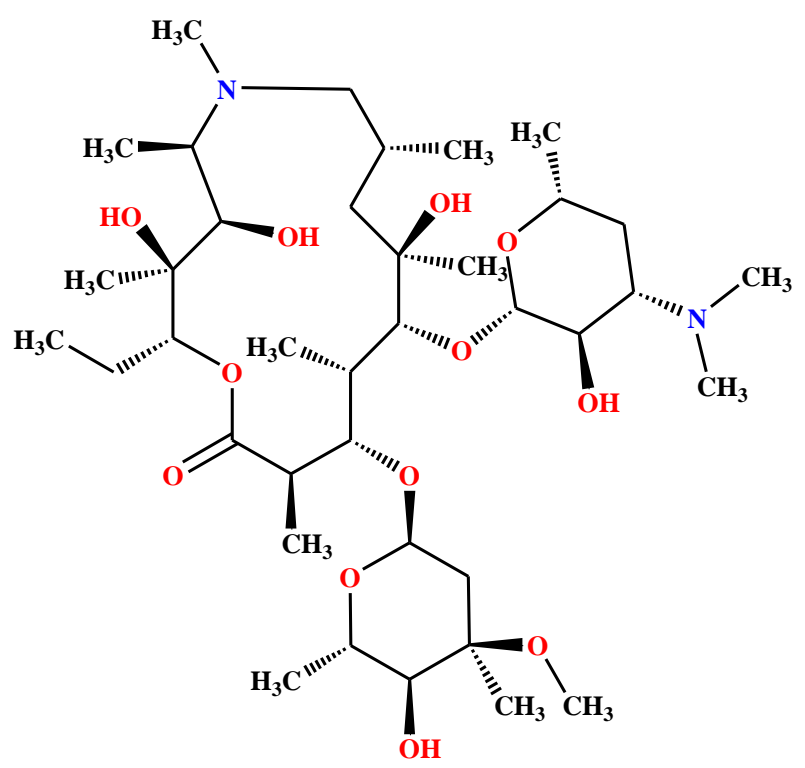

Figure 4. Structure of Azithromycin

\subsubsection{Role of Azithromycin in COVID-19}

AZ has been proposed as a viable therapeutic for the treatment of SARS-CoV-2 infection due to its anti-inflammatory and immunomodulatory effects, and its superior safety profile ${ }^{61,62}$. It prevents bacterial protein synthesis and translation and has additional immunomodulatory activity. It is extensively absorbed by tissue, especially the lungs, tonsils, and prostate ${ }^{63}$. It has an $\mathrm{EC}_{50}$ of $2.1 \mu \mathrm{M}$ on VeroE6 cells at an MOI of 0.002 for antiviral activity against SARS-CoV-2 ${ }^{64}$. Azithromycin can elevate the $\mathrm{pH}$ of the Golgi network and recycle endosomes ${ }^{65}$, interfering with SARS-CoV-2 activity and reproduction within the cell ${ }^{66}$. Because the virus is thought to have a furin-like cleavage site in the spike protein, AZ is known to suppress the enzyme furin, which interacts with SARS-COV-2 to enable virus entrance into cells ${ }^{67}$.

SARS-CoV-2 reaches the cell primarily by glycosylation of hACE2 ${ }^{68,69}$. During this phase, SARS-CoV-2 uses plasmatic membrane components such as gangliosides (particularly GM-1) as attachment co-factors inside lipid raft membrane platforms ${ }^{69}$. Recent quantum mechanical simulations of the SARS-CoV-2 virus revealed that AZ may play a role in preventing viral entrance by binding to SARS-CoV-2 spike protein and the host receptor ACE- $2^{70}$. By inhibiting the interaction points between SARS-CoV-2 and the ACE-2 receptor, AZ prevents SARS-CoV-2 from entering host cells ${ }^{71}$. AZ has become utilized in a third of sufferers treated for MERS-CoV, even without medical proof of it ${ }^{72}$. A $500 \mathrm{mg}$ dose of $\mathrm{AZ}$ is a common antibiotic used in primary care for bacterial respiratory infections, and it is similar to the dosage used in the early COVID-19 trials ${ }^{62}$. It is widely distributed throughout tissue, particularly the lungs, where typical concentrations in extracellular fluids and inside cells are significantly higher than in plasma ${ }^{73}$. AZ is safe, with a lower risk of side effects ${ }^{74}$. 
Repurposing of approved medicine in the management of COVID-19 infection

\subsection{Levamisole - an Anti-helminthic Drug}

Levamisole (LVM) (Figure 5) is a synthetic anti-helminthic agent with a low molecular weight ${ }^{75}$. It improves cellular immunity depending on the amount and timing of injection ${ }^{6,76}$, and also enhances the immunological response of T helper type 1 cells $^{77}$.

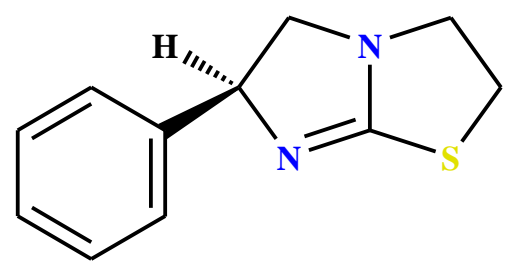

Figure 5. Structure of Levamisole

\subsubsection{Role of Levamisole in Covid-19}

LVM is one of the suggested drugs used for systemic treatment of COVID-19 because of its broad spectrum of immunological effects, including regulation of neutrophils, macrophages, and T-cell function. ${ }^{78}$. It also affects human interferon (IFNs), interleukin-6 (IL-6), and IL-8 levels ${ }^{79,80}$, and enhances IgA and IgM levels in blood ${ }^{81}$. LMS, as an immunostimulant, is thought to enhance lymphocytes and boost the body's immunity ${ }^{82}$. It also attaches to the virus shell's papain-like protease (PL-pro), which is required for COVID-19 pathogenicity, lowers TNF and IL-6 levels, and introduces the virus to the immune system as a chemical adjuvant ${ }^{83}$. LVM and ascorbic acid aggregate were proven to counteract the stressed helper/inducer subpopulation of lymphocytes in an in-vitro study ${ }^{75}$. Furthermore, in-vitro investigations demonstrated that the lymphocyte abnormalities could be duplicated in lymphocytes treated with $\mathrm{LVM}^{78}$. As a result, LVM could be suggested to treat COVID$19^{80,84}$.

\subsection{Doxycycline (DOX) - a Tetracycline Antibiotic}

Doxycycline (DOX) (Figure 6) is classified under tetracycline derivative and used to treat inflammation and immunomodulation ${ }^{85}$. It inhibits bacterial protein synthesis via binding to $30 \mathrm{~S}$ and possibly $50 \mathrm{~S}$ ribosomes in an irreversible manner, causing changes in cytoplasmic membrane. ${ }^{86-91}$. DOX is well-known for suppressing metalloproteinases (MMPs), particularly MMP-9, which is thought to be required for initial viral entry into the cell ${ }^{92}$. In addition, DOX inhibits interleukin (IL)-6, which, together with MMPs, is a vital regulator of the cytokine storm that is frequently associated with severe viral pneumonitis ${ }^{93-95}$.<smiles>C[C@@H]1[C@H]2C(=C(O)[C@]3(O)C(=O)C(C(N)=O)=C(O)[C@H](N(C)C)[C@H]3[C@@H]2O)C(=O)c2c(O)cccc2[C@@H]1C</smiles>

Figure 6. Structure of Doxycycline 


\subsubsection{Role of Doxycycline in COVID-19}

DOX has no recognized direct specificity for SARS-CoV-2 inhibition ${ }^{96}$. However, DOX in all likelihood, has towards recognized co-receptors DPP4/CD26, via verified inhibition of NF- $\mathrm{\kappa B}{ }^{97,98}$ and co-receptor CD147/EMMPRIN, which is needed for SARS-CoV-2 entry into T lymphocytes, even at sub-microbial doses ${ }^{99,100}$. DOX also inhibits the center-receptor CD147, which is required to have SARS-CoV-2 access into T lymphocytes ${ }^{101}$. It has been shown to have anti-SARS-CoV-2 action in vitro on infected Vero E6 cells. Additionally, It's in vitro antiviral activity towards a clinical isolate of SARSCoV2 established promising outcomes via interacting with the virus at entry and post-entry stages ${ }^{102}$. Docking evaluation confirmed that DOX could firmly bind to the SARS-CoV-2 spike protein (S) ${ }^{103}$. Furthermore, DOX and, more broadly, other tetracyclines can bind to the main protease (Mpro) of SARS-CoV-2, also known as 3C-like protease, which is required for SARS-CoV-2 replication by causing the formation of non-structural proteins (NSPs) ${ }^{104,105}$.

\subsection{Ivermectin (IVM) - an Anti-Parasitic Agent}

Ivermectin (IVM) (Figure 7) is a macrocyclic lactone having broad-spectrum of antiparasitic pharmacological action. It is a combination of 22, 23-dihydro-avermectin B1a (80\%) as well as 22, 23dihydro-avermectin B1b (20\%) ${ }^{106}$. It acts by binding to glutamate-mediated chlorine channels to cause cell membrane hyperpolarization, obstructing inhibitory neurotransmission through neurons and myocytes, resulting in paralysis and death ${ }^{107}$. Moreover, IVM significantly reduced the production of inflammatory cytokines such as TNF- $\alpha$, IL-1, and IL-6 in lipopolysaccharide (LPS)-induced inflammation ${ }^{108}$.

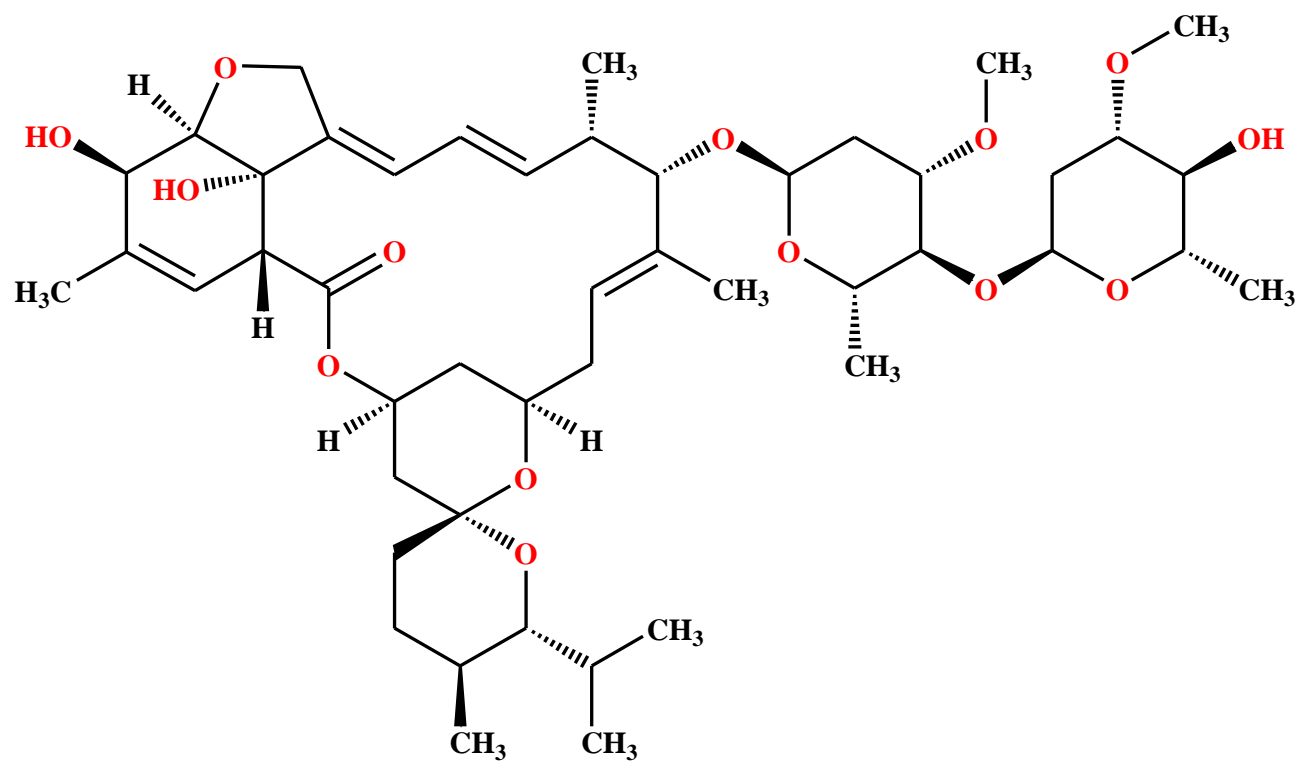

Figure 7. Structure of Ivermectin

\subsubsection{Role of Ivermectin in COVID-19}

IVM suppressed severe acute respiratory syndrome-coronavirus 2 (SARS-CoV-2) in-vitro, resulting in a 5,000-fold decrease in viral RNA after 48 hours using IVM at $5 \mu \mathrm{M}^{109}$. A $50 \%$ inhibitory concentration $\left(\mathrm{IC}_{50}\right)$ of $2 \mu \mathrm{M}(1,750 \mathrm{ng} / \mathrm{mL})$ is more than 35 times higher than the maximum plasma concentration $\left(\mathrm{C}_{\max }\right)$ of $0.05 \mathrm{M}(46.6 \mathrm{ng} / \mathrm{mL})$, following oral administration of the authorized dose (200 $\mathrm{g} / \mathrm{kg}$ ). At the same time, IVM exhibited little to no action at $1 \mu \mathrm{M}$ in vitro. Even though IVM is strongly bound to serum albumin $(93 \%)$, its $\mathrm{IC}_{50}$ orders of magnitude is greater than the unbound plasma $\mathrm{C}_{\max }$ following authorized ivermectin dosages $(0.0035 \mathrm{M} ; 3.26 \mathrm{ng} / \mathrm{mL}){ }^{110}$. By binding to the importin- $\alpha$ 
Repurposing of approved medicine in the management of COVID-19 infection

(IMP- $\alpha$ ) and importin- $\beta$ (IMP- $\beta$ ) heterodimer, SARS-CoV-2 protein is translocated into the nucleus via the nuclear pore complex (NPC). The importin- $\alpha / \beta$ complex releases the SARS-CoV-2 protein once it reaches the nucleus. The SARS-CoV-2 protein then promotes host shut-off, lowering the host's immunological response and allows the virus to replicate. IVM binds to the importin- $\alpha / \beta$ complex and destabilizes the importin-/ heterodimer, preventing SARS-CoV-2 protein translocation into the nucleus [Figure (8)]. The IVM treatment most likely promotes the efficient occurrence of host immune responses. Even though these data showed the potential usage of IVM as an antiviral medication in the battle against COVID-19; the dose employed was 200 times higher than that typically being used in clinical applications ${ }^{111}$. Moreover, a few observational studies and a real-world clinical practice demonstrated that IVM seems effective in treating COVID-19 patients at both mild-moderate and severe stages of the disease, suggesting that IVM may have antiviral but also immunomodulatory activities ${ }^{112-}$ 115 .

Furthermore, ivermectin-doxycycline had been tolerated well than hydroxychloroquine with azithromycin treatment. Based on this analysis, IVM is feasible for individuals infected with mild to moderate COVID-19 infection ${ }^{116}$. A total of 140 individuals having COVID-19 were studied in a randomized control trial. In contrast to usual treatment, 70 individuals had oral Ivermectin $200 \mathrm{mg}$ daily for 2 or 3 days and oral doxycycline $100 \mathrm{mg}$ twice daily for 5 to 10 days, while 70 individuals throughout the control group received normal treatment. The IVM group had a lower risk of progression to more severe illness and death, and a considerably shorter time towards recovery ${ }^{117}$.

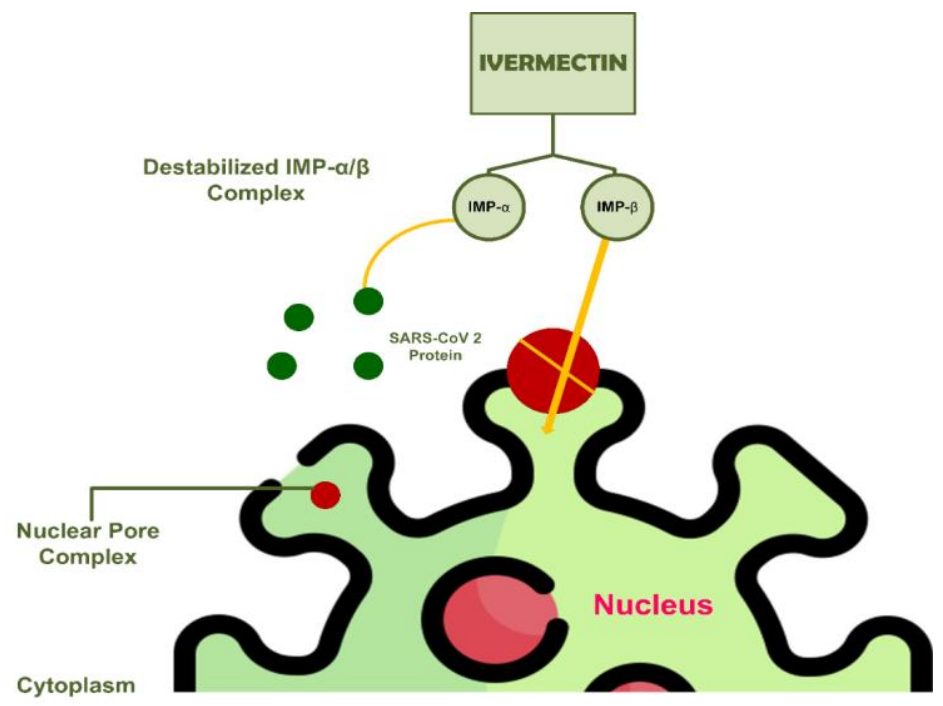

Figure 8. Role of Ivermectin in COVID-19

\subsection{Thalidomide (TLD) - an Anti-Neoplastic Agent}

Thalidomide (TLD), (Figure 9) also known as phocomelia, was launched as an antiinflammatory medication with extraordinary success in various autoimmune illnesses. Then, because of its multifunctional capabilities such as anti-angiogenesis, anti-fibrotic, immune regulatory effects, and anti-inflammatory, it is widely sold and promoted across the world ${ }^{118}$. Furthermore, TLD has been demonstrated to stimulate $\mathrm{T}$ cell receptors and T cells, improving immunological function ${ }^{119}$. 
Patel et al., Org. Commun. (2022) 15:1 1-31

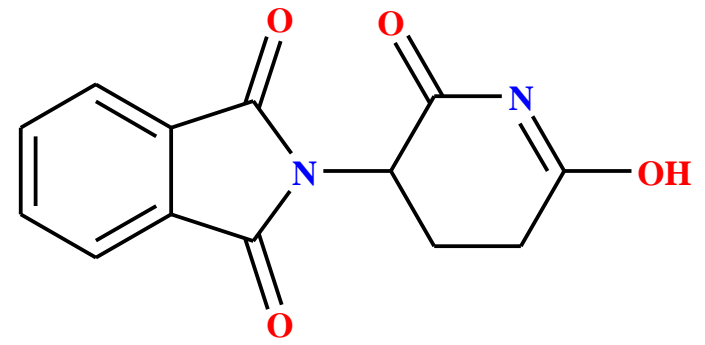

Figure 9. Structure of Thalidomide

\subsubsection{Role of Thalidomide in COVID-19}

TLD, a drug known to cause interstitial pulmonary fibrosis, paraquat lung injury, and myeloma, was suggested to function in the therapy of COVID-19. ${ }^{120,121}$. TLD reduces the transcription of IL-1 and IL-6 in human lung epithelial cells, which might also help preventing emphysema ${ }^{122}$. TNF $\alpha$, IL-1 $\beta$, IL-6, and transforming growth factor were reduced by TLD ${ }^{123}$. Furthermore, it could enhance interleukin production, like IL-12, thus, activating natural killer cells ${ }^{124}$. In addition, TLD inhibits activated NF- $\kappa B$, responsible for malignant cell proliferation, inflammation and angiogenesis, including poorly-regulated immunological responses ${ }^{125-128}$. When used with the COX-2 inhibitor such as celecoxib, TLD has had an immunomodulatory impact; together, these drugs reduce the production of pro-inflammatory cytokines such as TNF- $\alpha$ and interleukin ${ }^{129}$, potentially reducing the activity of the IKB kinase, which inhibits NF- $\kappa B{ }^{130}$. TNF- $\alpha$, IL-6, IL-1, and TGF- $\beta$ are the central pro-inflammatory cytokines that underpin the pathogenicity of these diseases, and they are shared by both paraquat and bleomycin-induced pulmonary fibrosis models ${ }^{123,131}$. Because of its anti-inflammatory and immunoregulatory properties, TLD, combined with low-dose steroids, could treat COVID-19 pneumonia $^{132}$.

\subsection{Cyclosporine (CSA) - an Immunosuppressive Agent}

Cyclosporine (CSA) (Figure 10) is a significant immunosuppressive drug that is frequently used in immunosuppression during organ transplantation. In addition, rheumatologists frequently use it to treat vasculitis ${ }^{133}$.

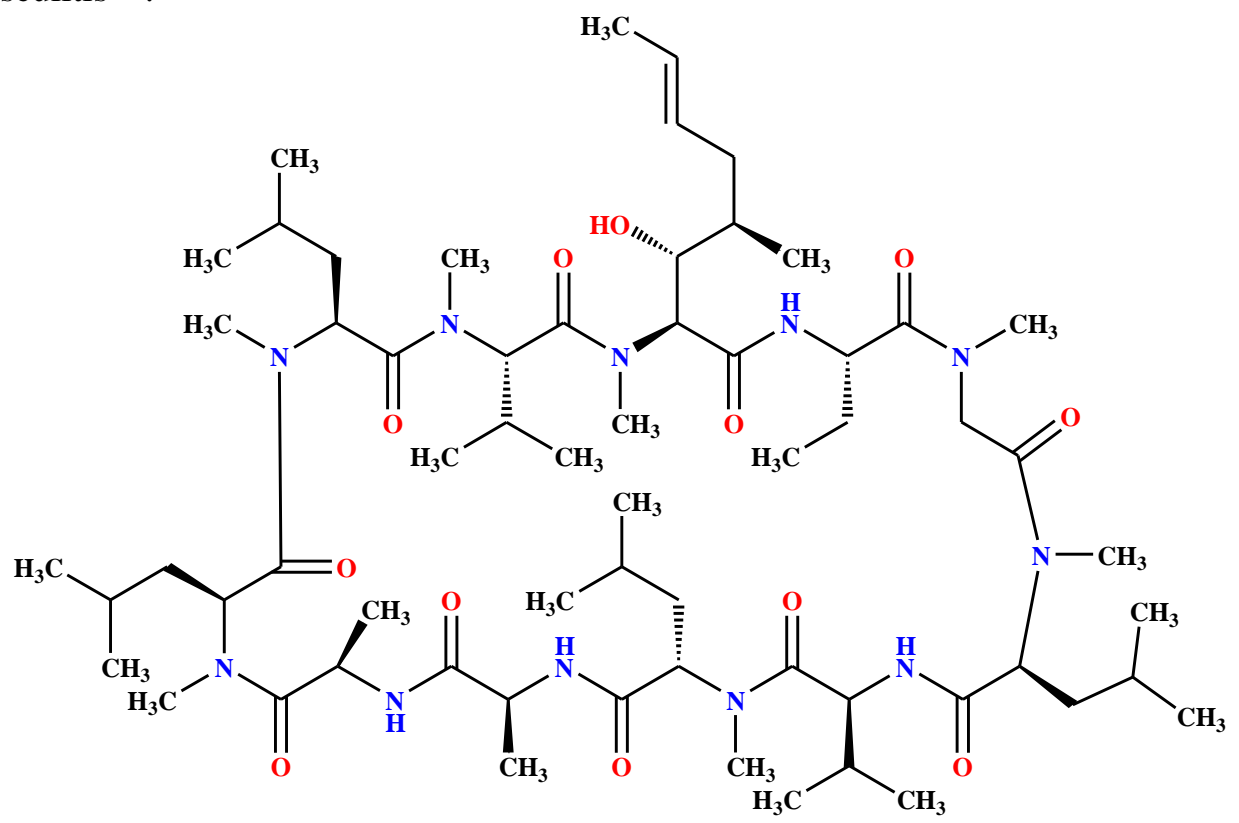

Figure 10. Structure of Cyclosporine 
Repurposing of approved medicine in the management of COVID-19 infection

It is a natural product, which is an 11-amino acid cyclic polypeptide derived from the fungus Tolypocladium inflatum. CSA is an immunosuppressant that suppresses or weakens the immune system.

\subsubsection{Role of Cyclosporine in COVID-19}

CSA has been found to suppress the production of various coronaviruses in vitro, including SARS-CoV-2, MERS-CoV (Figure 11A) ${ }^{134-136}$. It has immunosuppressive as well as anti-inflammatory actions via reducing interleukin-2 (IL-2) production by inhibiting the activation of the nuclear factor of activated T cells (NF-AT) (Figure 11B) ${ }^{137}$. Because SARS-CoV-2 non-structural protein might promote IL-2 production via NF-AT recruitment, CSA may help in reducing the risk of the cytokine storm in moderate COVID-19 ${ }^{138}$. Cyclosporine seems to be a calcineurin inhibitor that suppresses the synthesis of calcium-dependent interleukin (IL)-2. It inhibits calcineurin activity in the cell by complexing with cyclophilin and decreases IL-2 gene transcription ${ }^{139}$. At relatively low and non-toxic dosages, CSA has been demonstrated to reduce SARS-CoV-2 viral replication ${ }^{135,140,141}$. NFAT inhibition eventually results in the suppression of cytokine transcription and, as a result, T cell activation ${ }^{140,}{ }^{142-148}$. CSA inhibits replicating coronavirus groups (including SARS-CoV-1) in cell cultures at low micromolar and noncytotoxic doses ${ }^{140,} 144$. Also, it inhibits cyclophilin-D, which can prevent viral replication ${ }^{144,} 149$. Moreover, CSA binds CYP-D. It suppresses the opening, including its mitochondrial permeability transition pore (mPTP); essential pathophysiological activity caused by damage (e.g., oxidative stress, hypoxia, and ischemia/reperfusion) which can affect cell function for survival (Figure 11C) ${ }^{149}$. However, CSA toxicity at concentrations that might be necessary to suppress SARS-CoV-2 cannot be ruled out 140, 144, 149, 150 . Comprehensive expense analysis should be performed before evaluating CSA for human clinical trials to treat COVID-19, given the diversity of adverse effects such as greater sensitivity to infections, nausea, vomiting, and cancer development, amongst others ${ }^{151}$.

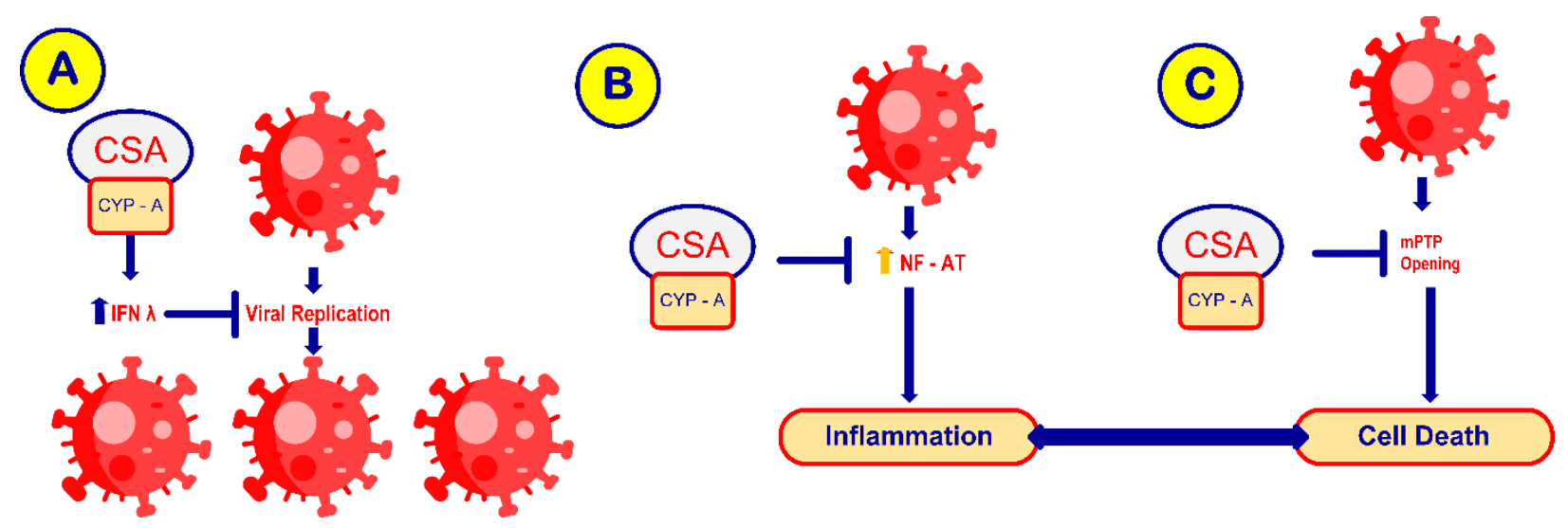

Figure 11. Role of Cyclosporin in COVID 19

\subsection{Rapamycin (RAPA) - a Macrolide Lactone Antibiotic}

Rapamycin (RAPA) (Figure 12) is a hydrophobic macrocyclic lactone antibiotic discovered from Streptomyces hygroscopicus by fermentation method ${ }^{152-154}$. Furthermore, it was detected for its first time in soil actinomycete gathered from Atari region of Eastern Island ${ }^{155}$. Although RAPA was first considered as an anti-fungal drug, its immunosuppressive characteristics were discovered in $1988^{155}$. Furthermore, anti-cancer activity was discovered in the 1990 s, which led to the creation and deployment of semi-synthetic rapamycin analogs, exhibiting superior oncology properties (e.g., everolimus, temsirolimus) ${ }^{156,157}$.

In 1991, the serine-threonine kinase mammalian target of RAPA (mTOR) was identified as a component of the rapamycin mechanism of action ${ }^{158,159}$. mTOR is a protein kinase that belongs to the phosphatidylinositol 3-kinase (PI3K)-related kinase family ${ }^{160}$. The TOR receptor reacts to various 
Patel et al., Org. Commun. (2022) 15:1 1-31

normal and pathological stimuli, thus controlling cell growth and proliferation ${ }^{161,162}$. The TOR signaling pathway comprises two distinct multiprotein complexes termed TOR complex 1 (TORC1) and TORC2, both responsive and insensitive towards RAPA ${ }^{163}$. Because of the activation of ribosomal protein S6, p70S6K, including 4E-BP1, mTORC1 controls protein synthesis, autophagy, and other cellular activities, whereas mTORC2 is required for maximum stimulation of numerous kinases, including AKT (Protein Kinase B) ${ }^{164}$. Furthermore, RAPA binds to the immunophilin, FK-binding protein 12, to form an immunosuppressive complex, which binds to that and inhibits TTOR $^{165}$. Sirolimus seems to be an mTOR inhibitor (rather than a calcineurin inhibitor), reducing cytokine synthesis and T-lymphocyte activation or proliferation.

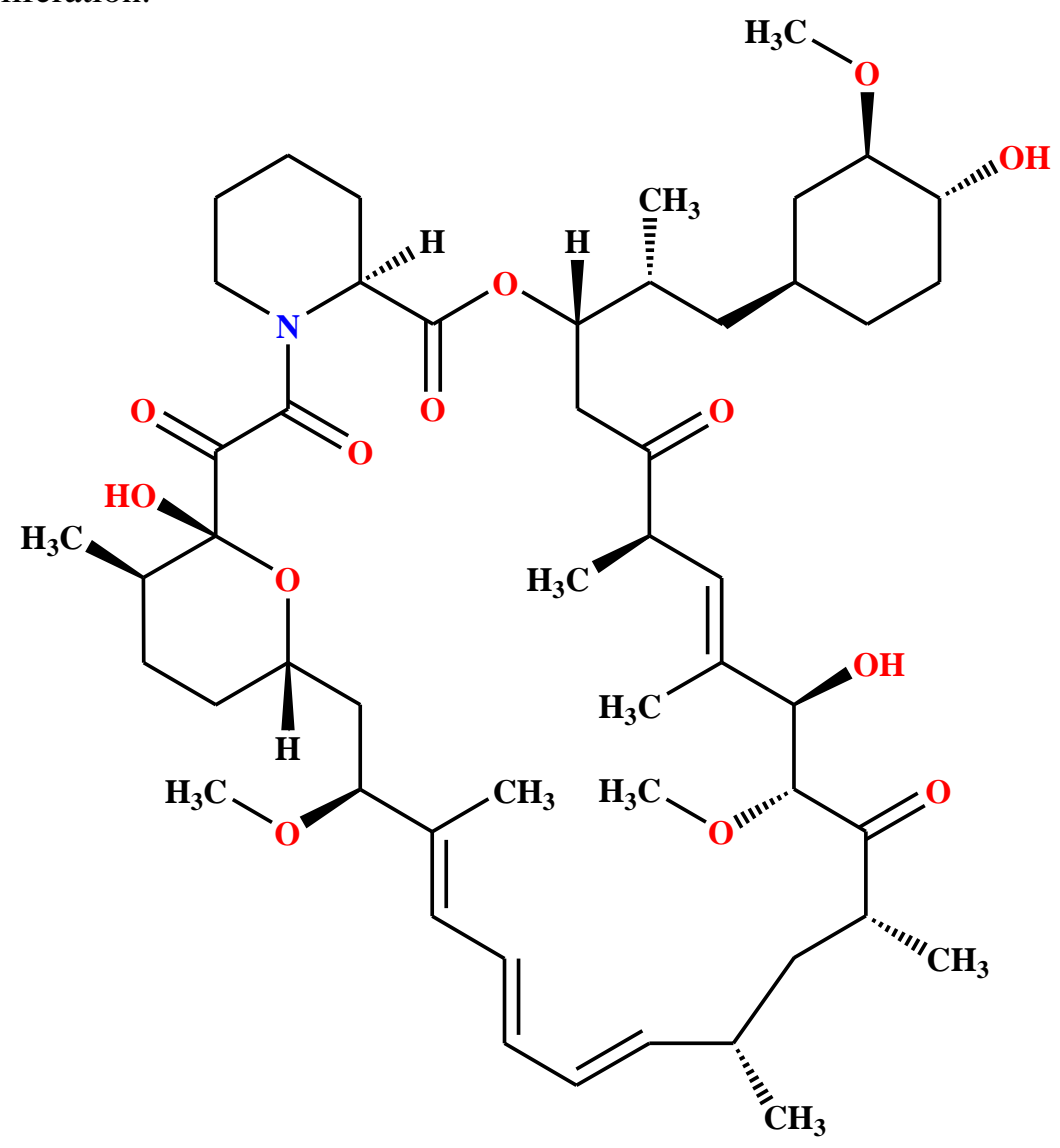

Figure 12. Structure of Rapamycin

\subsubsection{Role of Rapamycin in COVID-19}

mTOR pathways within COVID-19 could provide significant targets for controlling cell damage, oxidative stress, or the beginning of hyper inflammation ${ }^{166}$. mTOR generates two complexes; (i) mTORC1 mediates TH1 and TH17 proliferation after viral antigenic transmission by dendritic cells (DC) ${ }^{167}$, and (ii) mTORC2 mediates TH2 production, and both ligands inhibit T-cell differentiation ${ }^{168}$. Because the mTOR pathway is vital in many biological activities, it is not unexpected that it governs the growth and response of several immune cells ${ }^{169}$. mTOR regulates their gene expression for myeloid immune cells, which controls its migration and cytokine expression. Inhibiting mTORC1 enhances dendritic cell (DC) $\mathrm{T}$ cell stimulatory activity and activates macrophage autophagy ${ }^{160}$. In $\mathrm{T}$ cells, mTORC1 action is caused via oxidative stress, which may be prevented as $\mathrm{N}$-acetylcysteine to patients having systemic lupus erythematosus (SLE) ${ }^{170}$. mTORC1 activation is engaged with SLE patients that could be inhibited with RAPA, consistent with its function for pro-inflammatory T-cell differentiation 168 .

Moreover, the mTOR pathway is essential for B cell development. mTORC1 controls the fates of B cells throughout the germinal center by regulating BCL6 expression ${ }^{160}$. Following B cell activation, 
Repurposing of approved medicine in the management of COVID-19 infection

mTORC1 inhibition lowers the numbers of antigen-specific memory B cells ${ }^{171}$. RAPA therapy inhibits anti-IgM-stimulated murine B cell proliferation, preventing B cellular proliferation ${ }^{172,}{ }^{173}$. In addition, mTOR inhibitors, RAPA, including ATP-competitive inhibitors (INK128, PP242, Ku-0063794, and AZD8055), have been shown to reduce early B-cell generation within germinal centers ${ }^{174,175}$. As an mTOR inhibitor, RAPA prevents the cell cycle from progressing from G1 to S. SARS-CoV-2 interaction to human proteins such as LARP1 and FKBP7, regulated by mTORC1 pathway. It was demonstrated that mTOR is a critical route to SARS-CoV-2 infection ${ }^{164}$. The over-activation, including its immune system caused by infection, induces the cytokine storm through severe COVID-19 patients, resulting in multiple organ failure and death ${ }^{176}$. Under these situations, IL-2, IL-6, IL-7, IL-10, TNF- $\alpha$, G-CSF, IP10, MCP-1 (monocyte chemoattractant protein), or even MIP-1 (Macrophage Inflammatory Proteins) might be implicated with TH17 type reactions. Both TNF- $\alpha$ and IL-1 (TH17 and TH1 cells both express TNF-) increase TH17 responses and vascular permeability and leakage. COVID-19 promotes the development of TH17 cells, which contributes to a TH17-type cytokine storm throughout this disease ${ }^{22}$. T-cell apoptosis, necrosis, and pyroptosis may also be induced by a cytokine storm, resulting in decreased T-cell numbers ${ }^{177}$.

RAPA, an immunosuppressant, is known to reduce the production of various cytokines such as IL-6, IL-2, and IL-10, can also regulate a cytokine storm in COVID-19 patients ${ }^{164}$. As a result of its pleiotropic inhibitory effect in various cytokines and other essential pathways linked to protein synthesis, ageing, and obesity are controlled by mTORC1, Rapamycin provides several benefits ${ }^{164}$. Furthermore, both the H1N1 influenza virus and now the SARS-CoV-2 virus activate both mTOR but also NLRP3 inflammasome pathways ${ }^{166,}{ }^{178}$, resulting in the generation for IL-1 $\beta$, a mediator of lung inflammation, fever, and fibrosis ${ }^{166,179}$, as well as pyroptosis, a hyperinflammatory type of cell death ${ }^{180}$. RAPA suppresses H1N1-induced activation of the mTOR pathway, including IL-1 production ${ }^{178}$. Furthermore, RAPA might suppress the attachment of SARS-CoV-2 to Toll-Like Receptor (TLR), ultimately leading to IL-1 $\beta$ production in COVID-19181. Furthermore, RAPA induces de novo Foxp3 expression in naïve T cells, resulting in Treg proliferation and survival in vivo and in vitro. As a result, RAPA reduces effector T-cell proliferation while increasing treg accumulation ${ }^{167}$. RAPA had been recently discovered as an option for possible usage in COVID-19 in a network-based medication repurposing research ${ }^{181}$. When administered early in the cytokine storm phase, RAPA may prevent progression toward severe types of COVID-19 by down-regulating a SASP, its mTOR-NLRP3-IL-1 axis, the IL-6 pathway, as well as senescent T-cell population.

\subsection{Tocilizumab (TZB) - a Monoclonal Antibody}

Tocilizumab (TZB) is a monoclonal anti-IL-6 $\alpha$ receptor inhibiting antibody used to treat inflammatory disorders ${ }^{182}$. Numerous genetic indicators, such as FCGR3A, IL6R, CD69, and GALNT18, have been implicated in the effectiveness of TZB through RA ${ }^{183-185}$. On the other hand, variables of CD69 and GALNT18 are expected to have minor direct impacts on TZB. Variants in these genes are more likely to affect the immune system's downstream, signaling pathways in RA patients, which could limit their use in non-RA patients ${ }^{185}$. TZB is a recombinantly humanized anti-human IL6R monoclonal antibody of the IgG1 class. TZB suppresses signal transmission by binding to soluble and membrane-bound IL-6 receptors (sIL-6R and mIL-6R). It is approved to treat rheumatoid arthritis ${ }^{186}$ and systemic juvenile idiopathic arthritis ${ }^{187}$. In addition, TZB is helpful in diagnosis of patients with severe $\mathrm{CRS}^{188,189}$.

\subsubsection{Role of Tocilizumab in COVID-19}

TZB might be used to treat COVID-19-related CRS, similar to how it is used to treat CRS, caused by chimeric antigen receptor T-cell treatment ${ }^{190}$. In observational studies in the United States and around the world, TZB improved outcomes in patients with COVID-19 pneumonia, pointing to the possible importance of TZB in the therapy of CRS, the critical function of IL-6 in CRS, and the critical role of CRS in the pathogenesis of SARS-CoV-2 ARDS ${ }^{191-193}$. Randomized studies with TZB, on the other hand, have had mixed results in people with diverse degrees of COVID-19 disease severity and 
Patel et al., Org. Commun. (2022) 15:1 1-31

populations with varying baseline levels of care ${ }^{194-197}$. For example, in a trial of 15 COVID-19 patients, 8 were given TZB in combination with prednisolone, and 7 were given TZB separately, frequently, or even more. TZB therapy effectively reduced serum interleukin-6 levels throughout all patients. However, even though the CRP rate quickly recovered the baseline, it was not statistically significant in four critically sick patients who received only one dose of TZB ${ }^{198}$.

Case reports have mentioned improvements in patients with severe COVID-19 pneumonia who received TZB ${ }^{199-201}$. Retrospective observational cohort studies have found a rapid reduction in fever, a reduction in the need for oxygen support or mechanical ventilation, and an improvement in lung manifestations $191,198,202$. As a result, IL-6 antagonists such as siltuximab, tocilizumab, and sarilumab have been recommended as supplemental therapy for severe, progressive COVID19. TZB, on the other hand, has been demonstrated to have a putative function in specific case studies ${ }^{191,198,203-205}$.

\subsection{Sarilumab (SRB) - a Monoclonal Antibody}

Sarilumab (SRB) appears to be a monoclonal antibody that targets interleukin-6 receptor. A biologic response modifier and the disease-modifying antirheumatic drug is a recombinant human IgG1 kappa monoclonal antibody specific for interleukin-6 (IL-6) receptor (DMARD). SRB is a biological medication used to treat moderate to severe active rheumatoid arthritis who have not responded to or tolerated prior treatments. It can be taken on its own or combined with other disease-modifying antirheumatic drugs (DMARDs) like methotrexate ${ }^{206}$.

\subsubsection{Role of Sarilumab in COVID-19}

The food and drug administration (FDA) has approved SRB to treat rheumatoid arthritis (RA) and the off-label usage of this medicine for treating COVID-19 has also been studied ${ }^{207-210}$. Although SRB suppresses both soluble and membrane-bound versions of the IL-6 receptor ${ }^{206,211}$, it may reduce pro-inflammatory signaling in pulmonary epithelial or immune cells ${ }^{212}$. Therefore, COVID-19 patients should be watched for simultaneous infections, particularly severe potentially life-threatening diseases such as tuberculosis (TB), invasive fungal, bacterial, viral, other opportunistic infections, and localized conditions, given the function of IL-6 in the immune system ${ }^{206}$.

Sarilumab is an anti-IL-6 receptor antibody that was first studied in an open-label trial of 28 patients with COVID-19 pneumonia. No changes in mortality or treatment outcomes found when compared to the standard of care were reported ${ }^{213}$. In addition, a study of 53 people with acute COVID-19 pneumonia discovered that after a median follow-up of 19 days, up to $90 \%$ of patients significantly improved, and $71 \%$ was eventually discharged with sarilumab therapy ${ }^{214}$. There was a $10 \%$ risk of significant risk factors resulting in mortality in $29 \%$ of sarilumab-treated patients, However, they failed to demonstrate significant improvement in critical and ventilated COVID-19 patients ${ }^{215,216}$.

\subsection{Nitazoxanide (NTZ) - an Antiprotozoal Agents}

Nitazoxanide (NTZ) (Figure 13) is a prototype of a family of chemicals called thiazole derivative, initially synthesized in the early $1970 \mathrm{~s}^{217,218}$. NTZ, also known as 2-(acetyloxy)-N-(5-nitro2-thiazolyl) benzamide, is an anti-infective medication that suppresses external survival, growth, and proliferation and intracellular protozoa, helminths, anaerobic and microaerophilic bacteria, as well as viruses. NTZ has also been discovered to have anti-inflammatory properties ${ }^{219}$. NTZ has shown potential as a broad-spectrum antibacterial and antiviral medication in addition to its principal activity as an antiparasitic ${ }^{220}$. 
Repurposing of approved medicine in the management of COVID-19 infection<smiles>CC(=O)Oc1ccccc1C(=O)Nc1ncc([N+](=O)[O-])s1</smiles>

Figure 13. Structure of Nitazoxanide

\subsubsection{Role of Nitazoxanide in COVID 19}

NTZ has previously been found to have antiviral activity against MERS-CoV and other coronaviruses in vitro; it is also known to boost interferon production ${ }^{221}$. NTZ inhibited bovine coronavirus (L9), murine coronavirus, mouse hepatitis virus (A59), and a human enteric coronavirus (4408) cultured in mouse astrocytoma (DBT) and fibroblast (17Cl-1) cell lines with an $\mathrm{IC}_{50}$ of about 0.3 $\mathrm{g} / \mathrm{ml}$. This was achieved via the reduction of viral $\mathrm{N}$ protein production ${ }^{222}$. NTZ also inhibits the production of pro-inflammatory cytokines ${ }^{221}$. Generally, COVID-19 therapy lasts for 7-14 days. Thus, NTZ is safe to be used for this length of time ${ }^{223}$. The ability of NTZ to balance pro-inflammatory and anti-inflammatory responses in humans could play a key role in COVID-19 by reducing the hyperinflammatory cytokine storm ${ }^{221,224-226}$. NTZ inhibits viral infection by upregulating host mechanisms that viruses utilize to overcome host cellular defenses. Although in-vitro efficacy of NTZ towards SARS-CoV-2 is promising, additional research is needed to understand its function in COVID-19 treatment ${ }^{227}$. Unfortunately, studies on the effectiveness of NTZ toward human coronavirus are few. Many research groups suggested having efficacy against COVID-19; however, the potential utility is yet to be explored in dose frequency 228 .

\subsection{Interferons - a class of signaling protein}

In innate and adaptive immune responses, interferons (IFNs), are a class of signaling proteins that play a critical role in limiting viral reproduction via diverse effector proteins ${ }^{229,230}$. A cell produces interferon (IFN), a type of cytokine, when it is triggered by a viral infection or another interferon (IFN) inducing agent. It is a secreted protein (primarily a glycoprotein) with a broad spectrum of antiviral and immunoregulating physiologic capabilities and the modulation of innate and acquired immunological responses to infection. Interferon (IFN) is classified into three types; type I, type II, and Type III. Type I interferons (IFN- $\alpha / \beta$ ) have extensive antiviral activity against RNA viruses, generating an antiviral response in various cell types or facilitating adaptive immune response. Humans develop 13 different kinds of IFN- $\alpha$ and a single IFN- $\beta{ }^{231}$. STING (stimulator of interferon genes, also known as ERIS/ MITA) and its downstream effector cyclic GMP-AMP synthase (cGAS) regulate transcription of a broad spectrum of inflammatory mediators type I and type III interferons ${ }^{231,232}$. The IFN- $\lambda$ family of cytokines (also known as type III interferons) is a relatively new class of cytokines that binds to various receptor complexes but activate the same JAK-STAT signaling pathway ${ }^{233-235}$. Furthermore, the IFN$\mathrm{R} 1$ receptor is primarily expressed in epithelial cells and organs, including respiratory epithelial cells.

\subsubsection{Role of Interferon in COVID-19}

IFNs, particularly IFN-1b, have been demonstrated to be effective against SARS and MERS coronaviruses and are now being explored for COVID-19 alone or in conjunction with other medications such as lopinavir and ritonavir ${ }^{236}$. Moreover, COVID-19 pathology, which primarily consists of pulmonary lesions, resembling interferonopathies. This may imply that SARS-CoV-2 produces an overactive IFN-I induced antiviral response, resulting in tissue damage. If this theory is validated, IFN- 
I therapy should be confined to the early stages of infection, ${ }^{237}$ Early clinical evidences, demonstrating severe inflammatory biomarkers, are linked with higher mortality ${ }^{238}$.

Recent research showed that type I IFN and IFN- $\lambda$ is not generated in COVID-19 patients since they were not identified in the serum of a small COVID-19 group with any unexplained clinical feature $^{239}$. In comparison, another research found that type I IFN is increased in COVID-19 patients, and, therefore, its concentration may be decreased in those severely sick patients ${ }^{240}$.

A latest study that looked at peripheral blood from patients with COVID-19 of different causes found that IFN-I responses seem to be severely impaired in patients with severe or essential COVID-19, as evidenced by low levels of IFN-I, ISGs and higher production of TNF- $\alpha$ and IL-6 or increased NF- $\mathrm{kB}-$ driven inflammatory responses ${ }^{240}$. However, there have been retroactive investigations on SARS-CoV2 and MERS-CoV using IFNs in combination with other treatments ${ }^{241}$. Although IFNs have been indicated for being effective in SARS and MERS-CoV by increasing lung function or delaying death, they have typically neglected to modify the illness in people ${ }^{242}$. As coronaviruses are so similar, studies have suggested that insufficient IFN production in response to SARS-CoV-2 causes the innate immune response being suppressed, resulting in higher viral levels. As a result, exogenous IFN may be more effective in treating SARS-CoV-2 infection than endogenous IFN ${ }^{243,244 .}$

\subsection{Favipiravir - Flu Virus Multiplication Inhibitor}

Favipiravir (FVP) is a purine analog (Figure 14) that is substituted for guanine or adenine ${ }^{245}$. Favipiravir, also known as T-705, was first created in 2002 as a flu virus multiplication inhibitor ${ }^{246}$. On February 15, 2020, China authorized FVP to treat the new influenza ${ }^{247}$. FVP has shown significant antiviral action on cell lines and animal studies against various segmented negative-strand RNA viruses such as arena and bunyaviruses. In addition, FVP has also been shown to have efficacy against positive-strand RNA viruses such as noroviruses and flaviviruses ${ }^{248-250}$.<smiles>NC(=O)c1nc(F)cnc1O</smiles>

Figure 14. Structure of Favipiravir

\subsubsection{Role of Favipiravir in COVID-19}

Favipiravir (FVP) is a prospective COVID-19 candidate medicine; however, while delivering it, drugdrug interactions with previously given medications must be examined, as they may change the pharmacokinetics and plasma concentration of favipiravir ${ }^{251}$. It is a RNA virus-specific and robust inhibitor of RNA-dependent RNA polymerase (RdRp). FVP is integrated into the nascent viral RNA via the error-prone viral RdRp, resulting in viral mutagenesis and chain termination. The presence of RdRp in several kinds of RNA viruses allows favipiravir to have a more extensive range of antiviral activity ${ }^{118,252,253}$. FVP -RTP acts as a mutagen after RNA viral inclusion, avoiding coronavirus repair machinery. Although it has been approved for use in such an emergency, large-scale studies are required to assess its role in the ongoing care of COVID-19. Eighty-five percent of COVID-19 patients have mild to moderate illnesses that might be managed at home. Thus, this medicine could help many people. Adults take a loading dosage of $1800 \mathrm{mg}$ followed by $800 \mathrm{mg}$ twice daily for up to 14 days, or a $1600 \mathrm{mg}$ loading dose followed by $600 \mathrm{mg}$ twice daily for up to 14 days $^{254}$. Due to its teratogenic effects, FVP cannot be given to expectant mothers or those who may become pregnant. In asymptomatic and mild patients, the rate of viral clearance with FVP (1800 mg regimen) was equal in both early (1 day after participation) and late (6 days after participation) treatment groups ${ }^{255}$. Due to effectiveness of the drug to use for treatment of COVID19 interrupted in many countries. 
Repurposing of approved medicine in the management of COVID-19 infection

\subsection{Molnupiravir - Pyrimidine Ribonucleoside Analogue}

Molnupiravir (MNP) (Figure 15) was designed to treat alphavirus infections in the first place. Molnupiravir, also known as methyl isobutyrate, is a pyrimidine ribonucleoside analog. EIDD-1931-isopropyl ester; EIDD-2801; MK-4482; uridine, 4-oxime, 50 -(2- methyl propanoate); and -D-N4-hydroxycytidine-50 isopropyl ester are some of the alternative names for MNP. It is an orally active, directly acting antiviral interventional medicine, and it is a potential forthcoming oral treatment ${ }^{256,257}$.<smiles></smiles>

Figure 15. Structure of Molnupiravir

\subsubsection{Role of Molnupiravir in COVID-19}

MNP, a prodrug of the ribonucleoside analog $\beta$-D-N4 -hydroxycytidine (NHC), is quickly transformed to NHC and subsequently to the active $5^{\prime}$-triphosphate form host kinases in the plasma. The active $5^{\prime}$-triphosphate is a competitive substrate for virally encoded RNA-dependent RNA polymerase (RdRp). If integrated into nascent viral RNA, it causes an antiviral impact by accumulating mutations that increase with each viral replication cycle $^{256,258}$. Mode of action of MNP is divided into two parts; incorporation and mutagenesis. MNP is a nucleoside analog that incorporates negative sRNA, causing favorable sRNA products to mispair. This mechanism results in fatal mutagenesis or viral inactivation ${ }^{259}, 260$. MNP works by causing a cascade of errors in the coronavirus DNA, and there have been fears that it may affect human genes. However, the panelists were provided data from in vivo studies demonstrating that adult were not at danger at therapeutic levels.

Nevertheless, the medicine will not be approved for use in pregnant or lactating women, and its future in children is unclear ${ }^{261}$. The phase three trial was placed in over 170 locations worldwide, including the United States, Brazil, Italy, South Africa, Japan, Taiwan, and Guatemala. According to the research, the start of symptoms or the existence of underlying risk factors in patients did not affect the efficacy of MNP. It also showed consistent activity against all SARS-CoV-2 variations, including the widely distributed and highly transmissible delta strain $^{262}$. In addition, MNP is an effective inhibitor of SARS-CoV-2 multiplication in cell line studies, with an $\mathrm{EC}_{50}$ in the submicromolar range; a similar viral injection effect has also been reported in animal models ${ }^{263}$.

Table 1. Proposed mechanism of action of the drugs repurposed for COVID-19

\begin{tabular}{|c|c|c|c|}
\hline Drugs used in COVID-19 & Category & $\begin{array}{c}\text { Proposed Mechanism } \\
\text { of action }\end{array}$ & Reference \\
\hline $\begin{array}{l}\text { Chloroquine and } \\
\text { Hydroxychloroquine }\end{array}$ & Anti-malarial & $\begin{array}{l}\text { ^Lysosomal } \mathrm{pH} \text { and } \\
\text { interfere with viral release }\end{array}$ & 32 \\
\hline Azithromycin & Macrolide Antibiotic & $\begin{array}{l}\text { It blocks internalization } \\
\text { into host cells during the } \\
\text { early phase of infection }\end{array}$ & 264 \\
\hline Levamisole & Anti-biotic & $\begin{array}{l}\text { Enhances the cellular } \\
\text { immunity; } \\
\text { immunostimulatory } \\
\text { functions }\end{array}$ & 58 \\
\hline
\end{tabular}


Patel et al., Org. Commun. (2022) 15:1 1-31

Table 1 continued.

\begin{tabular}{|c|c|c|c|}
\hline Doxycycline & $\begin{array}{l}\text { Semi synthetic } \\
\text { tetracycline antibiotic }\end{array}$ & $\begin{array}{l}\downarrow \text { Replication SARS- } \\
\text { COV2 } \downarrow \text { IL-6 levels }\end{array}$ & 78 \\
\hline Thalidomide & $\begin{array}{l}\text { Immunosuppressant and } \\
\text { sedative drug }\end{array}$ & $\begin{array}{l}\downarrow T N F-\alpha \downarrow \text { cell surface } \\
\text { adhesion molecules } \\
\text { involved in leukocyte } \\
\text { migration }\end{array}$ & 87 \\
\hline Cyclosporine & $\begin{array}{l}\text { Immunomodulatory } \\
\text { agent }\end{array}$ & $\begin{array}{l}\text { Inhibition of the } \\
\text { production of cytokines } \\
\text { involved in regulation of } t \\
\text { cell activation }\end{array}$ & 101,102 \\
\hline Rapamycin & Immunosuppressant & $\begin{array}{l}\text { Inhibits the secretion of } \\
\text { IL- } 6 \text { and other cytokines }\end{array}$ & 153 \\
\hline Ivermectin & $\begin{array}{l}\text { Used to treat parasitic } \\
\text { infections }\end{array}$ & $\begin{array}{l}\downarrow \text { Replication of SARS- } \\
\text { COV2 }\end{array}$ & 162 \\
\hline Tocilizumab & $\begin{array}{l}\text { Monoclonal Antibody- } \\
\text { IL-6 inhibitor (FDA } \\
\text { Granted) }\end{array}$ & $\begin{array}{l}\downarrow \text { IL- } 6 \text { interrupts the } \\
\text { process of CRS }\end{array}$ & $180,181,184$ \\
\hline Sarilumab & IL-6 inhibitor & $\downarrow$ Immune response $\downarrow$ IL-6 & 183 \\
\hline Nitazoxanide & $\begin{array}{l}\text { Antiviral and } \\
\text { antiparasitic - } \\
\text { Antiprotozoal agent }\end{array}$ & $\begin{array}{l}\text { Antiviral potential against } \\
\text { MERS-CoV and other } \\
\text { coronaviruses in in vitro }\end{array}$ & 198 \\
\hline Interferons & Antiviral & $\begin{array}{l}\text { Inhibits varying stages of } \\
\text { viral replication including } \\
\text { viral entry }\end{array}$ & 208 \\
\hline Favipiravir & Antiviral agent & $\begin{array}{l}\text { Inhibits RNA dependent } \\
\text { RNA polymerase, which } \\
\text { ultimately prevents viral } \\
\text { transcription }\end{array}$ & 248 \\
\hline Molnupiravir & Antiviral & $\begin{array}{l}\uparrow \text { Frequency of viral RNA } \\
\text { mutations }\end{array}$ & 258 \\
\hline
\end{tabular}

\section{Conclusion}

There are currently no approved, safe, and effective pharmacologic treatments for COVID-19 infection, and more research into all possible treatments is needed to address the virus. In Table 1, we incorporated mechanism of action of some already approved drugs used in COVID 19 viral infection. Also, as outcome, several pharmacologic medicines targeting distinct stages of viral activity have been identified. More clinical trials should be conducted as quickly as possible to evaluate prospective pharmacological medicines and determine the most effective way for reducing the transmission of this virus and the burden of any looming epidemic.

\section{List of Abbreviations}

- COVID-19 - Coronavirus Disease 2019

- SARS-Cov-2 - Severe Acute Respiratory Syndrome Coronavirus 2

- MERS - Middle East Respiratory Syndrome

- IL - Interleukin

- TNF - Tumor Necrosis Factor

- HCoV-OC43 - Human Coronavirus OC43 
Repurposing of approved medicine in the management of COVID-19 infection

- ACE2- Angiotensin Converting Enzyme 2

- NF-KB -Nuclear Factor-Kappa B

- HAS2 - Hyaluronan Synthase-2

- ARDS - Acute Respiratory Distress Syndrome

- $\mathrm{CQ}$ - Chloroquine

- HCQ - Hydroxychloroquine

- MAPK - Mitogen Activated Protein Kinase

- AZ - Azithromycin

- MOI - Multiplicity of infection

- LVM - Levamisole

- IFNs - Interferon

- DOX - Doxycycline

- MMPs - Metalloproteinases

- NSPs - Non-Structural Proteins

- TLD - Thalidomide

- CYS - Cyclosporine

- RAPA - Rapamycin

- Mtor - Mammalian target of rapamycin

- SLE - Systemic Lupus Erythematosus

- BCL6 - B-cell lymphoma 6

- IMP-Importin

- IVM - Ivermectin

- NPC -Nuclear pore complex

- $\mathrm{TZB}$ - Tocilizumab

- CRP- C-Reactive Protein

- SRB - Sarilumab

- DMARDs - Disease-Modifying Antirheumatic Medications

- NTZ - Nitazoxanide

- JAK-STAT - Janus Kinase - Signal Transducers and Activators of Transcription

- ISGs - Immune Serum Globulin

- FVP - Favipiravir

- MNP - Molnupiravir

- $\quad$ sRNA - Small RNA

- RdRp: RNA dependent RNA polymerase

\section{Acknowledgements}

The authors are thankful to Ramanbhai Patel College of Pharmacy and Charotar University of Science and Technology for providing necessary supports and facilities. 
Patel et al., Org. Commun. (2022) 15:1 1-31

\section{ORCID}

Darshini Patel: 0000-0001-9505-6960

Umang Shah: 0000-0001-6748-2137

Arya Patel: 0000-0002-8566-0926

Sandip Patel: 0000-0002-4954-4944

Mehul Patel: 0000-0002-2405-0243

Ashish Patel: $0000-0001-5773-3756$

Swayamprakash Patel: 0000-0002-6882-7042

Nilay Solanki: 0000-0003-1845-4740

Nilesh Pandey: 0000-0003-2937-3268

\section{References}

[1] Ahmed, S. S. The Coronavirus Disease 2019 (COVID-19): A Review. J. Adv. Med. Med. Res., 2020, 32 (4), 1-9.

[2] WHO, 2020. Naming the Coronavirus Disease (COVID-19) and the Virus That Causes It. Geneva, Switzerland: World Health Organization.

[3] Groot, J.D.; Baker, S.C.; Baric, R.S.; Brown, C.S.; Drosten, C.; Enjuanes, L.; Fouchier, R.A.M.; Galiano, M.; Gorbalenya, A.E.; Memish; Z.A.; et.al. Commentary: Middle East respiratory syndrome coronavirus (MERS-CoV): Announcement of the Coronavirus Study Group. J. Virol. 2013, 87 (14), 7790-7792.

[4] Lauer, S. A.; Grantz, K. H.; Bi, Q.; Jones, F. K.; Zheng, Q.; Meredith, H. R.; Azman, A. S.; Reich, N. G.; Lessler, J. The incubation period of Coronavirus Disease 2019 (COVID-19) from publicly reported confirmed cases: Estimation and application. Ann. Intern. Med. 2020, 172 (9), 577-582.

[5] Backer, J. A.; Klinkenberg, D.; Wallinga, J. Incubation period of 2019 novel coronavirus (2019-ncov) infections among travellers from Wuhan, China, 20-28 January 2020. Euro Surveill. Bull. Eur. sur les Mal. Transm. = Eur. Commun. Dis. Bull. 2020, 25 (5).

[6] Huang, C.; Wang, Y.; Li, X.; Ren, L.; Zhao, J.; Hu, Y.; Zhang, L.; Fan, G.; Xu, J.; Gu, X. et.al. Clinical features of patients infected with 2019 novel coronavirus in Wuhan, China. Lancet 2020, 395 (10223), 497-506.

[7] Gupta, A.; Madhavan, M. V; Sehgal, K.; Nair, N.; Mahajan, S.; Sehrawat, T. S.; Bikdeli, B.; Ahluwalia, N.; Ausiello, J. C.; Wan, E. Y. et.al. Extrapulmonary manifestations of COVID-19. Nat. Med. 2020, 26 (7), 1017-1032.

[8] Carfì, A.; Bernabei, R.; Landi, F. Persistent symptoms in patients after acute COVID-19. JAMA, 2020, $324(6), 603-605$.

[9] Tenforde, M. W.; Kim, S. S.; Lindsell, C. J.; Billig Rose, E.; Shapiro, N. I.; Files, D. C.; Gibbs, K. W.; Erickson, H. L.; Steingrub, J. S.; Smithline, H. A.; et al. Symptom duration and risk factors for delayed return to usual health among outpatients with COVID-19 in a multistate health care systems network United States, March-June 2020. MMWR. Morb. Mortal. Wkly. Rep. 2020, 69 (30), 993-998.

[10] Huang, C.; Huang, L.; Wang, Y.; Li, X.; Ren, L.; Gu, X.; Kang, L.; Guo, L.; Liu, M.; Zhou, X.; et al. 6Month consequences of COVID-19 in patients discharged from hospital: a cohort study. Lancet 2021, 397 (10270), 220-232.

[11] Chan, J. F.-W.; Kok, K.-H.; Zhu, Z.; Chu, H.; To, K. K.-W.; Yuan, S.; Yuen, K.-Y. Genomic characterization of the 2019 novel human-pathogenic coronavirus isolated from a patient with atypical pneumonia after visiting Wuhan. Emerg. Microbes Infect. 2020, 9 (1), 221-236.

[12] Wishart, D. S.; Feunang, Y. D.; Guo, A. C.; Lo, E. J.; Marcu, A.; Grant, J. R.; Sajed, T.; Johnson, D.; Li, C.; Sayeeda, Z.; et al. DrugBank 5.0: A major update to the Drugbank database for 2018. Nucleic Acids Res. 2018, 46 (D1), D1074-D1082.

[13] Lundin, A.; Dijkman, R.; Bergström, T.; Kann, N.; Adamiak, B.; Hannoun, C.; Kindler, E.; Jónsdóttir, H. R.; Muth, D.; Kint, J.; et al. targeting membrane-bound viral rna synthesis reveals potent inhibition of diverse coronaviruses including the Middle East respiratory syndrome virus. PLoS Pathog. 2014, 10 (5), e1004166.

[14] Pizzorno, A.; Padey, B.; Dubois, J.; Julien, T.; Traversier, A.; Dulière, V.; Brun, P.; Lina, B.; RosaCalatrava, M.; Terrier, O. In vitro evaluation of antiviral activity of single and combined repurposable drugs against SARS-CoV-2. Antiviral Res. 2020, 181, 104878. 
Repurposing of approved medicine in the management of COVID-19 infection

[15] Sheahan, T. P.; Sims, A. C.; Zhou, S.; Graham, R. L.; Pruijssers, A. J.; Agostini, M. L.; Leist, S. R.; Schäfer, A.; Dinnon, K. H. 3rd; Stevens, L. J.; et al. An orally bioavailable broad-spectrum antiviral inhibits SARS-CoV-2 in Human airway epithelial cell cultures and multiple coronaviruses in mice. Sci. Transl. Med. 2020, 12 (541).

[16] Chen, J. Pathogenicity and transmissibility of 2019-NCoV-A Quick overview and comparison with other emerging viruses. Microbes Infect. 2020, 22 (2), 69-71.

[17] Harrison, A. G.; Lin, T.; Wang, P. Mechanisms of SARS-CoV-2 transmission and pathogenesis. Trends Immunol. 2020, 41 (12), 1100-1115.

[18] Verdecchia, P.; Cavallini, C.; Spanevello, A.; Angeli, F. The pivotal link between ACE2 deficiency and SARS-CoV-2 infection. Eur. J. Intern. Med. 2020, 76, 14-20.

[19] Letko, M.; Marzi, A.; Munster, V. Functional assessment of cell entry and receptor usage for SARS-CoV2 and other lineage b betacoronaviruses. Nat. Microbiol. 2020, 5 (4), 562-569.

[20] Guo, Y.-R.; Cao, Q.-D.; Hong, Z.-S.; Tan, Y.-Y.; Chen, S.-D.; Jin, H.-J.; Tan, K.-S.; Wang, D.-Y.; Yan, Y. The origin, transmission and clinical therapies on coronavirus disease 2019 (COVID-19) outbreak - an update on the status. Mil. Med. Res. 2020, 7 (1), 11.

[21] Zhang, R.; Wang, X.; Ni, L.; Di, X.; Ma, B.; Niu, S.; Liu, C.; Reiter, R. J. COVID-19: Melatonin as a potential adjuvant treatment. Life Sci. 2020, 250, 117583.

[22] Wu, D.; Yang, X. O. TH17 responses in cytokine storm of COVID-19: an emerging target of JAK2 inhibitor fedratinib. J. Microbiol. Immunol. Infect. 2020, 53 (3), 368-370.

[23] Bell, T. J.; Brand, O. J.; Morgan, D. J.; Salek-Ardakani, S.; Jagger, C.; Fujimori, T.; Cholewa, L.; Tilakaratna, V.; Östling, J.; Thomas, M.; et al. Defective lung function following influenza virus is due to prolonged, reversible hyaluronan synthesis. Matrix Biol. 2019, 80, 14-28.

[24] Wang, D.; Hu, B.; Hu, C.; Zhu, F.; Liu, X.; Zhang, J.; Wang, B.; Xiang, H.; Cheng, Z.; Xiong, Y.; et al. clinical characteristics of 138 hospitalized patients with 2019 novel coronavirus-infected pneumonia in Wuhan, China. JAMA 2020, 323 (11), 1061-1069.

[25] Mehta, P.; McAuley, D. F.; Brown, M.; Sanchez, E.; Tattersall, R. S.; Manson, J. J. COVID-19: consider cytokine storm syndromes and immunosuppression. Lancet March 2020, 1033-1034.

[26] Chen, N.; Zhou, M.; Dong, X.; Qu, J.; Gong, F.; Han, Y.; Qiu, Y.; Wang, J.; Liu, Y.; Wei, Y.; et al. Epidemiological and clinical characteristics of 99 cases of 2019 novel coronavirus pneumonia in Wuhan, China: a descriptive study. Lancet 2020, 395 (10223), 507-513.

[27] Hällgren, R.; Samuelsson, T.; Laurent, T. C.; Modig, J. Accumulation of hyaluronan (hyaluronic acid) in the lung in adult respiratory distress syndrome. Am. Rev. Respir. Dis. 1989, 139 (3), 682-687.

[28] Hamming, I.; Timens, W.; Bulthuis, M. L. C.; Lely, A. T.; Navis, G. J.; van Goor, H. Tissue distribution of ACE2 protein, the functional receptor for SARS coronavirus. a first step in understanding SARS pathogenesis. J. Pathol. 2004, 203 (2), 631-637.

[29] Jin, G.; Wong, S. T. C. Toward better drug repositioning: prioritizing and integrating existing methods into efficient pipelines. Drug Discov. Today 2014, 19 (5), 637-644.

[30] Shameer, K.; Readhead, B.; Dudley, J. T. Computational and experimental advances in drug repositioning for accelerated therapeutic stratification. Curr. Top. Med. Chem.. 2015, 15 (1), 5-20.

[31] Sun, P.; Guo, J.; Winnenburg, R.; Baumbach, J. Drug repurposing by integrated literature mining and drug-gene-disease triangulation. Drug Discov. Today 2017, 22 (4), 615-619.

[32] Khan, Z.; Karataş, Y.; Ceylan, A. F.; Rahman, H. COVID-19 and therapeutic drugs repurposing in hand: the need for collaborative efforts. Le Pharmacien Hospitali Clinicien. March 2021, pp 3-11.

[33] Doan, T. L.; Pollastri, M.; Walters, M. A.; Georg, G. I. Chapter 23 - the future of drug repositioning: old drugs, new opportunities; Macor, J. E. B. T.-A. R. in M. C., Ed.; Academic Press, 2011; Vol. 46, pp 385401.

[34] Ashburn, T. T.; Thor, K. B. Drug repositioning: identifying and developing new uses for existing drugs. Nat. Rev. Drug Discov. 2004, 3 (8), 673-683.

[35] Pushpakom, S.; Iorio, F.; Eyers, P. A.; Escott, K. J.; Hopper, S.; Wells, A.; Doig, A.; Guilliams, T.; Latimer, J.; McNamee, C.; et al. Drug repurposing: progress, challenges and recommendations. Nat. Rev. Drug Discov. 2018, 18 (1), 41-58.

[36] Rothan, H. A.; Byrareddy, S. N. The Epidemiology and pathogenesis of coronavirus disease (COVID-19) outbreak. J. Autoimmun. 2020, 109, 102433.

[37] Paolini, G. V; Shapland, R. H. B.; van Hoorn, W. P.; Mason, J. S.; Hopkins, A. L. Global mapping of pharmacological space. Nat. Biotechnol. 2006, 24 (7), 805-815.

[38] Koch, U.; Hamacher, M.; Nussbaumer, P. Cheminformatics at the interface of medicinal chemistry and proteomics. Biochim. Biophys. Acta 2014, 1844 (1 Pt A), 156-161. 
[39] Achan, J.; Talisuna, A. O.; Erhart, A.; Yeka, A.; Tibenderana, J. K.; Baliraine, F. N.; Rosenthal, P. J.; D'Alessandro, U. Quinine, an old anti-malarial drug in a modern world: role in the treatment of malaria. Malar. J. 2011, 10 (1), 144.

[40] Pastick, K. A.; Okafor, E. C.; Wang, F.; Lofgren, S. M.; Skipper, C. P.; Nicol, M. R.; Pullen, M. F.; Rajasingham, R.; McDonald, E. G.; Lee, T. C.; et al. Review: Hydroxychloroquine and Chloroquine for Treatment of SARS-CoV-2 (COVID-19). Open Forum Infect. Dis. 2020, 7 (4), ofaa130. doi: 10.1093/ofid/ofaa130

[41] WHO Guidelines for Malaria.

[42] Villegas, L.; McGready, R.; Htway, M.; Paw, M. K.; Pimanpanarak, M.; Arunjerdja, R.; Viladpai-Nguen, S. J.; Greenwood, B.; White, N. J.; Nosten, F. Chloroquine Prophylaxis against vivax malaria in pregnancy: a randomized, double-blind, placebo-controlled trial. Trop. Med. Int. Health 2007, 12 (2), 209218.

[43] McGready, R.; Lee, S. J.; Wiladphaingern, J.; Ashley, E. A.; Rijken, M. J.; Boel, M.; Simpson, J. A.; Paw, M. K.; Pimanpanarak, M.; Mu, O.; et al. Adverse effects of falciparum and vivax malaria and the safety of antimalarial treatment in early pregnancy: a population-based study. Lancet. Infect. Dis. 2012, 12 (5), 388-396.

[44] Liu, J.; Cao, R.; Xu, M.; Wang, X.; Zhang, H.; Hu, H.; Li, Y.; Hu, Z.; Zhong, W.; Wang, M. Hydroxychloroquine, a less toxic derivative of chloroquine, is effective in inhibiting sars-cov-2 infection in vitro. Cell Discov. 2020, 6, 16.

[45] Devaux, C. A.; Rolain, J.-M.; Colson, P.; Raoult, D. New Insights on the antiviral effects of chloroquine against coronavirus: what to expect for COVID-19? Int. J. Antimicrob. Agent. 2020, 55 (5), 105938.

[46] Colson, P.; Rolain, J.-M.; Lagier, J.-C.; Brouqui, P.; Raoult, D. Chloroquine and hydroxychloroquine as available weapons to fight COVID-19. Int. J. Antimicrob. Agent. April 2020, 105932.

[47] Gao, J.; Tian, Z.; Yang, X. breakthrough: chloroquine phosphate has shown apparent efficacy in treatment of COVID-19 associated pneumonia in clinical studies. Biosci. Trend. 2020, 14 (1), 72-73.

[48] Oscanoa, T. J.; Romero-Ortuno, R.; Carvajal, A.; Savarino, A. A Pharmacological perspective of chloroquine in SARS-CoV-2 infection: an old drug for the fight against a new coronavirus? Int. J. Antimicrob. Agent. 2020, 56 (3), 106078.

[49] Schrezenmeier, E.; Dörner, T. Mechanisms of action of hydroxychloroquine and chloroquine: implications for rheumatology. Nat. Rev. Rheumatol. 2020, 16 (3), 155-166.

[50] Smit, C.; Peeters, M. Y. M.; van den Anker, J. N.; Knibbe, C. A. J. Chloroquine for SARS-CoV-2: Implications of its unique pharmacokinetic and safety properties. Clin. Pharmacokinet. 2020, 59 (6), 659669.

[51] WHO Discontinues hydroxychloroquine and lopinavir/ritonavir treatment arms for COVID-19.

[52] Ibáñez, S.; Martínez, O.; Valenzuela, F.; Silva, F.; Valenzuela, O. Hydroxychloroquine and chloroquine in COVID-19: should they be used as standard therapy? Clin. Rheumatol. 2020, 39 (8), 2461-2465.

[53] Salvi, R.; Patankar, P. Emerging pharmacotherapies for COVID-19. Biomed. Pharmacother. 2020, 128, 110267.

[54] Simmons, G.; Bertram, S.; Glowacka, I.; Steffen, I.; Chaipan, C.; Agudelo, J.; Lu, K.; Rennekamp, A. J.; Hofmann, H.; Bates, P.; et al. Different host cell proteases activate the SARS-Coronavirus spike-protein for cell-cell and virus-cell fusion. Virology 2011, 413 (2), 265-274.

[55] Wang, M.; Cao, R.; Zhang, L.; Yang, X.; Liu, J.; Xu, M.; Shi, Z.; Hu, Z.; Zhong, W.; Xiao, G. Remdesivir and chloroquine effectively inhibit the recently emerged novel coronavirus (2019-NCoV) in vitro. Cell Res. 2020, 30 (3) 269-271.

[56] Seitz, M.; Valbracht, J.; Quach, J.; Lotz, M. Gold sodium thiomalate and chloroquine inhibit cytokine production in monocytic THP-1 cells through distinct transcriptional and posttranslational mechanisms. $J$. Clin. Immunol. 2003, 23 (6), 477-484.

[57] Briant, L.; Robert-Hebmann, V.; Acquaviva, C.; Pelchen-Matthews, A.; Marsh, M.; Devaux, C. The protein tyrosine kinase P56lck Is required for triggering NF-KappaB activation upon interaction of human immunodeficiency virus type 1 envelope glycoprotein Gp120 with cell surface CD4. J. Virol. 1998, 72 (7), 6207-6214.

[58] Yang, Q.; Xie, L.; Zhang, W.; Zhao, L.; Wu, H.; Jiang, J.; Zou, J.; Liu, J.; Wu, J.; Chen, Y.; et al. Analysis of the clinical characteristics, drug treatments and prognoses of 136 patients with coronavirus disease 2019. J. Clin. Pharm. Ther. 2020, 45 (4), 609-616.

[59] Bakheit, A. H. H.; Al-Hadiya, B. M. H.; Abd-Elgalil, A. A. Azithromycin. Profiles Drug Subst. Excip. Relat. Methodol., 2014, 39, 1-40.

[60] Zarogoulidis, P.; Papanas, N.; Kioumis, I.; Chatzaki, E.; Maltezos, E.; Zarogoulidis, K. Macrolides: From in vitro anti-inflammatory and immunomodulatory properties to clinical practice in respiratory diseases. Eur. J. Clin. Pharmacol. 2012, 68 (5), 479-503. 
Repurposing of approved medicine in the management of COVID-19 infection

[61] Parnham, M. J.; Erakovic Haber, V.; Giamarellos-Bourboulis, E. J.; Perletti, G.; Verleden, G. M.; Vos, R. Azithromycin: mechanisms of action and their relevance for clinical applications. Pharmacol. Ther. 2014, 143 (2), 225-245.

[62] Gautret, P.; Lagier, J.-C.; Parola, P.; Hoang, V. T.; Meddeb, L.; Mailhe, M.; Doudier, B.; Courjon, J.; Giordanengo, V.; Vieira, V. E.; et al. Hydroxychloroquine and azithromycin as a treatment of COVID-19: results of an open-label non-randomized clinical trial. Int. J. Antimicrob. Agent. 2020, 56 (1), 105949.

[63] McMullan, B. J.; Mostaghim, M. Prescribing azithromycin. Aust. Prescr. 2015, 38 (3), 87-89.

[64] Touret, F.; Gilles, M.; Barral, K.; Nougairède, A.; van Helden, J.; Decroly, E.; de Lamballerie, X.; Coutard, B. In vitro screening of a fda approved chemical library reveals potential inhibitors of SARS-CoV-2 replication. Sci. Rep. 2020, 10 (1), 13093.

[65] Poschet, J. F.; Perkett, E. A.; Timmins, G. S.; Deretic, V. Azithromycin and Ciprofloxacin Have a Chloroquine-like Effect on Respiratory Epithelial Cells. bioRxiv : The Preprint Server for Biology, March 2020. doi: $10.1101 / 2020.03 .29 .008631$

[66] Butler, C.C.; Dorward, J.; Yu, L.M.; Gbinige, O.; Hayward, G.; Saville, B.R.; Hecke, O.V.; Berry, N.; Detry, M.; Saunders, C. et.al. Azithromycin for community treatment of suspected COVID-19 in people at increased risk of an adverse clinical course in the UK (PRINCIPLE): A randomised, controlled, openlabel, adaptive platform trial. Lancet 2021, 397 (10279), 1063-1074.

[67] Coutard, B.; Valle, C.; de Lamballerie, X.; Canard, B.; Seidah, N. G.; Decroly, E. The spike glycoprotein of the new coronavirus 2019-NCoV contains a furin-like cleavage site absent in CoV of the same clade. Antiviral Res. 2020, 176, 104742.

[68] Alexander, S. P. H.; Armstrong, J. F.; Davenport, A. P.; Davies, J. A.; Faccenda, E.; Harding, S. D.; LeviSchaffer, F.; Maguire, J. J.; Pawson, A. J.; Southan, C.; et al. A rational roadmap for SARS-CoV2/COVID-19 pharmacotherapeutic research and development: IUPHAR Review 29. Br. J. Pharmacol. 2020, 177 (21), 4942-4966.

[69] Fantini, J.; Chahinian, H.; Yahi, N. Synergistic antiviral effect of hydroxychloroquine and azithromycin in combination against SARS-CoV-2: what molecular dynamics studies of virus-host interactions reveal. Int. J. Antimicrob. Agent. 2020, 56 (2), 106020.

[70] Sandeep, S.; McGregor, K. Energetics based modeling of hydroxychloroquine and azithromycin binding to the SARS-CoV-2 spike (S) protein - ACE2 complex. ChemRxiv, 2020. doi: 10.26434/chemrxiv.12015792.v2

[71] Al-Kuraishy, H.; Al-Naimi, M.; Lungnier, C.; Al-Gareeb, A. Macrolides and COVID-19: an optimum premise. Biomed. Biotechnol. Res. J. 2020, 4 (3), 189-192.

[72] Arabi, Y. M.; Deeb, A. M.; Al-Hameed, F.; Mandourah, Y.; Almekhlafi, G. A.; Sindi, A. A.; Al-Omari, A.; Shalhoub, S.; Mady, A.; Alraddadi, B.; et al. Macrolides in critically ill patients with middle east respiratory syndrome. Int. J. Infect. Dis. IJID Off. Publ. Int. Soc. Infect. Dis. 2019, 81, 184-190.

[73] Rodvold, K. A.; Gotfried, M. H.; Danziger, L. H.; Servi, R. J. Intrapulmonary steady-state concentrations of clarithromycin and azithromycin in healthy adult volunteers. Antimicrob. Agents Chemother. 1997, 41 (6), 1399-1402.

[74] Gorelik, E.; Masarwa, R.; Perlman, A.; Rotshild, V.; Muszkat, M.; Matok, I. Systematic review, metaanalysis, and network meta-analysis of the cardiovascular safety of macrolides. Antimicrob. Agents Chemother. 2018, 62 (6). doi:10.1128/AAC.00438-18

[75] Roostaei Firozabad, A.; Meybodi, Z. A.; Mousavinasab, S. R.; Sahebnasagh, A.; Jelodar, M. G.; Karimzadeh, I.; Habtemariam, S.; Saghafi, F. Efficacy and safety of levamisole treatment in clinical presentations of non-hospitalized patients with COVID-19: A double-blind, randomized, controlled trial. BMC Infect. Dis. 2021, 21 (1), 297.

[76] Lee, C.; Choi, W. J. Overview of COVID-19 Inflammatory pathogenesis from the therapeutic perspective. Arch. Pharm. Res. 2021, 44 (1), 99-116.

[77] Jin, H.; Li, Y.; Ma, Z.; Zhang, F.; Xie, Q.; Gu, D.; Wang, B. Effect of chemical adjuvants on dna vaccination. Vaccine 2004, 22 (21-22), 2925-2935.

[78] Roostaei A.; Meybodi, Z.A., ousavinasab, S. R.; Sahebnasagh, A.; Jelodar, M. G.; Karimzadeh, I.; Habtemariam, S.; Saghafi, F. Efficacy and safety of levamisole treatment in clinical presentations of patients with COVID-19. Research Square, 2021, 1-14. (https://assets.researchsquare.com/files/rs122376/v1/82c95ead-7ba7-44eb-8ea6-535847c3cede.pdf?c=1631869791)

[79] Renoux, G. The general immunopharmacology of levamisole. Drugs 1980, 20 (2), 89-99.

[80] Joffe, M. I.; Sukha, N. R.; Rabson, A. R. Lymphocyte subsets in measles. depressed helper/inducer subpopulation reversed by in vitro treatment with levamisole and ascorbic acid. J. Clin. Invest. 1983, 72 (3), 971-980. 
[81] Chamani DDS, G.; Rad DDS, M.; Reza Zarei DDS, M.; Reza Hashemimanesh DDS, S.; Abbaszadeh DDS, E.; Sadeghi, M. Effect of levamisole on treatment of recurrent aphthous stomatitis: a systematic review and meta-analysis. J. Oral Heal. Oral Epidemiol. 2016, 5 (2), 70-77.

[82] Uyaroğlu, O. A.; Güven, G. S.; Güllü, İ. Can levamisole be used in the treatment of COVID-19 patients presenting with diarrhea? J. Infect. Dev. Ctries. 2020, 14 (8), 844-846.

[83] Siamack Afazeli. Evaluation of efficacy of levamisole and formoterol+budesonide in treatment of COVID-19. ClinicalTrials.gov, https://clinicaltrials.gov/ct2/show/NCT04331470

[84] Rosenthal, M.; Trabert, U.; Müller, W. The effect of levamisole on peripheral blood lymphocyte subpopulations in patients with rheumatoid arthritis and ankylosing spondylitis. Clin. Exp. Immunol., 1976, 25 (3), 493-496.

[85] Kim, N.; Park, C.-S.; Im, S.-A.; Kim, J.-W.; Lee, J.-H.; Park, Y.-J.; Song, S.; Lee, C.-K. Minocycline promotes the generation of dendritic cells with regulatory properties. Oncotarget 2016, 7 (33), 5281852831.

[86] Blaser, J. B. R. D. M. J. Mandell, Douglas, and Bennett's principles and practice of infectious diseases, 9th ed.; Blaser, J. B. R. D. M. J., Ed.; Elsevier Inc, 2019.

[87] Karimian, P.; Delavar, M. A. Comparative study of clinical symptoms, laboratory results and imaging features of coronavirus and influenza virus, including similarities and differences of their pathogenesis. Pakistan J. Med. Heal. Sci. 2020, 14 (3), 1405-1411.

[88] Chopra, I.; Roberts, M. Tetracycline antibiotics: mode of action, applications, molecular biology, and epidemiology of bacterial resistance. Microbiol. Mol. Biol. Rev., 2001, 65 (2), 232-60 ; second page, table of contents.

[89] Grossman, T. H. Tetracycline antibiotics and resistance. Cold Spring Harb. Perspect. Med. 2016, 6 (4), a025387.

[90] Farrokhpour, M.; Rezaie, N.; Moradi, N.; Ghaffari Rad, F.; Izadi, S.; Azimi, M.; Zamani, F.; Izadi, S.; Ranjbar, M.; Jamshidi Makiani, M.; et al. Infliximab and intravenous gammaglobulin in hospitalized severe COVID-19 Patients in intensive care unit. Arch. Iran. Med. 2021, 24 (2), 139-143.

[91] Nojomi, M.; Yassin, Z.; Keyvani, H.; Makiani, M. J.; Roham, M.; Laali, A.; Dehghan, N.; Navaei, M.; Ranjbar, M. Effect of Arbidol (umifenovir) on COVID-19: A randomized controlled trial. BMC Infect. Dis. 2020, 20 (1), 954.

[92] Griffin, M. O.; Fricovsky, E.; Ceballos, G.; Villarreal, F. Tetracyclines: A Pleitropic family of compounds with promising therapeutic properties. review of the literature. Am. J. Physiol. Cell Physiol. 2010, 299 (3), C539-48.

[93] Kong, M. Y. F.; Whitley, R. J.; Peng, N.; Oster, R.; Schoeb, T. R.; Sullender, W.; Ambalavanan, N.; Clancy, J. P.; Gaggar, A.; Blalock, J. E. Matrix metalloproteinase-9 mediates rsv infection in vitro and in vivo. Viruses 2015, 7 (8), 4230-4253.

[94] Phillips, J. M.; Gallagher, T.; Weiss, S. R. Neurovirulent murine coronavirus JHM.SD uses cellular zinc metalloproteases for virus entry and cell-cell fusion. J. Virol. 2017, 91 (8), e01564-16.

[95] Conforti, C.; Giuffrida, R.; Zalaudek, I.; Di Meo, N. Doxycycline, a widely used antibiotic in dermatology with a possible anti-inflammatory action against IL-6 in COVID-19 outbreak. Dermatol. Therapy. 2020, e13437.

[96] Yates, P. A.; Newman, S. A.; Oshry, L. J.; Glassman, R. H.; Leone, A. M.; Reichel, E. Doxycycline treatment of high-risk covid-19-positive patients with comorbid pulmonary disease. Ther. Adv. Respir. Dis. 2020, 14, 1753466620951053.

[97] Santa-Cecília, F. V; Socias, B.; Ouidja, M. O.; Sepulveda-Diaz, J. E.; Acuña, L.; Silva, R. L.; Michel, P. P.; Del-Bel, E.; Cunha, T. M.; Raisman-Vozari, R. Doxycycline Suppresses microglial activation by inhibiting the P38 MAPK and NFf-KB signaling pathways. Neurotox. Res. 2016, 29 (4), 447-459.

[98] Choi, B.; Lee, S.; Kim, S.-M.; Lee, E.-J.; Lee, S. R.; Kim, D.-H.; Jang, J. Y.; Kang, S.-W.; Lee, K.-U.; Chang, E.-J.; et al. Dipeptidyl Peptidase-4 induces aortic valve calcification by inhibiting insulin-like growth factor-1 signaling in valvular interstitial Cells. Circulation, 2017, 135 (20), 1935-1950.

[99] Wang, X.; Xu, W.; Hu, G.; Xia, S.; Sun, Z.; Liu, Z.; Xie, Y.; Zhang, R.; Jiang, S.; Lu, L. RETRACTED ARTICLE: SARS-CoV-2 Infects T Lymphocytes through Its Spike Protein-Mediated Membrane Fusion. Cell. Mol. Immunol., 2020, 1-3.

[100] Emingil, G.; Atilla, G.; Sorsa, T.; Tervahartiala, T. The effect of adjunctive subantimicrobial dose doxycycline therapy on gcf emmprin levels in chronic periodontitis. J. Periodontol. 2008, 79 (3), 469 476.

[101] Acosta Saltos, F.; Acosta Saltos, A. . Entry of SARS-CoV2 through the Basal surface of alveolar endothelial cells - a proposed mechanism mediated by CD147 in COVID-19. Preprints 2020, 2020050359 (May). 
Repurposing of approved medicine in the management of COVID-19 infection

[102] Gendrot, M.; Andreani, J.; Jardot, P.; Hutter, S.; Delandre, O.; Boxberger, M.; Mosnier, J.; Le Bideau, M.; Duflot, I.; Fonta, I.; et al. In vitro antiviral activity of doxycycline against SARS-CoV-2. Molecules 2020, $25(21), 5064$.

[103] Sachdeva, C.; Wadhwa, A.; Kumari, A.; Hussain, F.; Jha, P.; Kaushik, N. K. In silico potential of approved antimalarial drugs for repurposing against COVID-19. OMICS, 2020, 24 (10), 568-580.

[104] Bharadwaj, S.; Lee, K. E.; Dwivedi, V. D.; Kang, S. G. Computational insights into tetracyclines as inhibitors against SARS-CoV-2 M(pro) via combinatorial molecular simulation calculations. Life Sci. 2020, 257, 118080.

[105] Sencanski, M.; Perovic, V.; Pajovic, S. B.; Adzic, M.; Paessler, S.; Glisic, S. Drug Repurposing for candidate SARS-CoV-2 main protease inhibitors by a novel in silico method. Molecules 2020, 25,3830.

[106] González Canga, A.; Sahagún Prieto, A. M.; Diez Liébana, M. J.; Fernández Martínez, N.; Sierra Vega, M.; García Vieitez, J. J. The pharmacokinetics and interactions of ivermectin in humans: a mini-review. AAPS J. 2008, 10 (1), 42-46.

[107] Geary, T. G. Ivermectin 20 years on: maturation of a wonder drug. Trends Parasitol. 2005, 21 (11), 530532.

[108] Zhang, X.; Song, Y.; Ci, X.; An, N.; Ju, Y.; Li, H.; Wang, X.; Han, C.; Cui, J.; Deng, X. Ivermectin inhibits lps-induced production of inflammatory cytokines and improves lps-induced survival in mice. Inflamm. Res. 2008, 57 (11), 524-529.

[109] Caly, L.; Druce, J. D.; Catton, M. G.; Jans, D. A.; Wagstaff, K. M. The FDA-approved drug ivermectin inhibits the replication of SARS-CoV-2 in vitro. Antiviral Res. 2020, 178, 104787.

[110] Klotz, U.; Ogbuokiri, J. E.; Okonkwo, P. O. Ivermectin binds avidly to plasma proteins. Eur. J. Clin. Pharmacol. 1990, 39 (6), 607-608.

[111] Peña-Silva, R.; Duffull, S. B.; Steer, A. C.; Jaramillo-Rincon, S. X.; Gwee, A.; Zhu, X. Pharmacokinetic Considerations on the repurposing of ivermectin for treatment of COVID-19. Br. J. Clin. Pharmacol. 2021, 87 (3), 1589-1590.

[112] Vora, A.; Arora, V. K.; Behera, D.; Tripathy, S. K. White paper on ivermectin as a potential therapy for COVID-19. The Ind. J. Tuberculos. 2020, 67 (3), 448-451.

[113] Mudatsir, M.; Yufika, A.; Nainu, F.; Frediansyah, A.; Megawati, D.; Pranata, A.; Mahdani, W.; Ichsan, I.; Dhama, K.; Harapan, H. Antiviral activity of ivermectin against SARS-CoV-2: an old-fashioned dog with a new trick - a literature review. Scientia Pharmaceut. 2020, 88,36, doi:10.3390/scipharm88030036

[114] Héctor, C.; Roberto, H.; Eugenia, F. M. Safety and Efficacy of the combined use of ivermectin, dexamethasone, enoxaparin and aspirin against COVID 19. medRxiv. 2020, 2020.09.10.20191619.

[115] Gorial, F. I.; Mashhadani, S.; Sayaly, H. M.; Dakhil, B. D.; AlMashhadani, M. M.; Aljabory, A. M.; Abbas, H. M.; Ghanim, M.; Rasheed, J. I. Effectiveness of ivermectin as add-on therapy in covid-19 management (pilot trial). medRxiv. 2020, 2020.07.07.20145979.

[116] Chowdhury, A. T. M. M.; Shahbaz, M.; Karim, M. R.; Islam, J.; Guo, D.; He, S. A Randomized Trial of ivermectin-doxycycline and hydroxychloroquine-azithromycin therapy on COVID19 patients. Research Square, 2021, 1-17. (https://assets.researchsquare.com/files/rs-38896/v1/3bcdb901-6d21-4243-a1190b395775e693.pdf?c=1631845759).

[117] Hashim, H. A.; Maulood, M. F.; Rasheed, A. M.; Fatak, D. F.; Kabah, K. K.; Abdulamir, A. S. Controlled randomized clinical trial on using ivermectin with doxycycline for treating covid-19 patients in Baghdad, Iraq. medRxiv. 2020, 2020.10.26.20219345.

[118] Shannon, E.; Noveck, R.; Sandoval, F.; Kamath, B. Thalidomide suppressed il-1beta while enhancing TNF-Alpha and IL-10, when cells in whole blood were stimulated with lipopolysaccharide. Immunopharmacol. Immunotoxicol. 2008, 30 (3), 447-457.

[119] Bartlett, J. B.; Dredge, K.; Dalgleish, A. G. The evolution of thalidomide and its IMiD derivatives as anticancer agents. Nat. Rev. Cancer 2004, 4 (4), 314-322.

[120] Kwon, H. Y.; Han, Y. J.; Im, J. H.; Baek, J. H.; Lee, J.-S. Two cases of immune reconstitution inflammatory syndrome in HIV patients treated with thalidomide. Int. J. STD AIDS. 2019, 30 (11), 11311135 .

[121] Moreira, A. L.; Corral, L. G.; Ye, W.; Johnson, B.; Stirling, D.; Muller, G. W.; Freedman, V. H.; Kaplan, G. Thalidomide and thalidomide analogs reduce hiv type 1 replication in human macrophages in vitro. AIDS Res. Hum. Retrovirus. 1997, 13 (10), 857-863.

[122] Tabata, C.; Tabata, R.; Takahashi, Y.; Nakamura, K.; Nakano, T. Thalidomide prevents cigarette smoke extract-induced lung damage in mice. Int. Immunopharmacol. 2015, 25 (2), 511-517.

[123] Amirshahrokhi, K. Anti-Inflammatory effect of thalidomide in paraquat-induced pulmonary injury in mice. Int. Immunopharmacol. 2013, 17 (2), 210-215. 
Patel et al., Org. Commun. (2022) 15:1 1-31

[124] Newfield, C. New medical indications for thalidomide and its derivatives. Sci. J. Lander Coll. Arts Sci. 2018, 12 (1), 3. (https://touroscholar.touro.edu/cgi/viewcontent.cgi?article=1201\&context=sjlcas)

[125] Majumdar, S.; Lamothe, B.; Aggarwal, B. B. Thalidomide suppresses NF-Kappa B activation induced by TNF and $\mathrm{H}_{2} \mathrm{O}_{2}$, but not that activated by ceramide, lipopolysaccharides, or phorbol ester. J. Immunol. 2002, 168 (6), 2644-2651.

[126] Darren W. Davis, Roy S. Herbst, J. L. A. Conventional therapeutics with antiangiogenic activity. In Antiangiogenic Cancer Therapy; Darren W. Davis, Roy S. Herbst, J. L. A., Ed.; CRC Press, Boca Raton, 2007, 289-317.

[127] Adamo, V.; Franchina, T.; Adamo, B.; Scandurra, G.; Scimone, A. Brain metastases in patients with nonsmall cell lung cancer: focus on the role of chemotherapy. Ann. Oncol. 2006, 17( Suppl 2), ii73-75.

[128] Tempfer, C. B.; Schultheis, B.; Hilal, Z.; Dogan, A.; Rezniczek, G. A. Thalidomide and lenalidomide for recurrent ovarian cancer: a systematic review of the literature. Oncol. Lett. 2017, 14 (3), 3327-3336.

[129] Gonzalez, A.; Sahaza, J. H.; Ortiz, B. L.; Restrepo, A.; Cano, L. E. Production of Pro-inflammatory cytokines during the early stages of experimental paracoccidioides brasiliensis infection. Med. Mycol. 2003, 41 (5), 391-399.

[130] Keifer, J. A.; Guttridge, D. C.; Ashburner, B. P.; Baldwin, A. S. J. Inhibition of NF-Kappa B activity by thalidomide through suppression of ikappab kinase activity. J. Biol. Chem., 2001, 276 (25), 22382-22387.

[131] Dong, X.; Li, X.; Li, M.; Chen, M.; Fan, Q.; Wei, W. Antiinflammation and antioxidant effects of thalidomide on pulmonary fibrosis in mice and human lung fibroblasts. Inflammation 2017, 40 (6), 18361846.

[132] Chen, C.; Qi, F.; Shi, K.; Li, Y.; Li, J.; Chen, Y.; Pan, J.; Zhou, T.; Lin, X.; Zhang, J.; et al. Thalidomide Combined with low-dose short-term glucocorticoid in the treatment of critical coronavirus disease 2019. Clin. Transl. Med. 2020, 10 (2), e35.

[133] Chighizola, C. B.; Ong, V. H.; Meroni, P. L. The use of cyclosporine a in rheumatology: a 2016 comprehensive review. Clin. Rev. Allergy Immunol. 2017, 52 (3), 401-423.

[134] Carbajo-Lozoya, J.; Ma-Lauer, Y.; Malešević, M.; Theuerkorn, M.; Kahlert, V.; Prell, E.; von Brunn, B.; Muth, D.; Baumert, T. F.; Drosten, C.; et al. Human coronavirus nl63 replication is cyclophilin adependent and inhibited by non-immunosuppressive cyclosporine a-derivatives including alisporivir. Virus Res. 2014, 184, 44-53.

[135] de Wilde, A. H.; Zevenhoven-Dobbe, J. C.; van der Meer, Y.; Thiel, V.; Narayanan, K.; Makino, S.; Snijder, E. J.; van Hemert, M. J. Cyclosporin a inhibits the replication of diverse coronaviruses. J. Gen. Virol. 2011, 92 (11), 2542-2548.

[136] Li, H. S.; Kuok, D. I. T.; Cheung, M. C.; Ng, M. M. T.; Ng, K. C.; Hui, K. P. Y.; Peiris, J. S. M.; Chan, M. C. W.; Nicholls, J. M. Effect of interferon alpha and cyclosporine treatment separately and in combination on middle east respiratory syndrome coronavirus (MERS-CoV) replication in a human invitro and ex-vivo culture model. Antiviral Res. 2018, 155, 89-96.

[137] Yashdeep Singh Pathania. Cyclosporine: hope for severe covid-19? BMJ Support. Palliativ Care 2021,0:1. doi:10.1136/bmjspcare-2020-002681

[138] Sanders, J. M.; Monogue, M. L.; Jodlowski, T. Z.; Cutrell, J. B. Pharmacologic treatments for coronavirus disease 2019 (COVID-19): a review. JAMA 2020, 323 (18), 1824-1836.

[139] Cure, E.; Kucuk, A.; Cumhur Cure, M. Cyclosporine therapy in cytokine storm due to coronavirus disease 2019 (COVID-19). Rheumatol. Int. 2020, 40 (7),1177-1179.

[140] Pfefferle, S.; Schöpf, J.; Kögl, M.; Friedel, C. C.; Müller, M. A.; Carbajo-Lozoya, J.; Stellberger, T.; von Dall'Armi, E.; Herzog, P.; Kallies, S.; et al. The SARS-Coronavirus-host interactome: identification of cyclophilins as target for pan-coronavirus inhibitors. PLoS Pathog. 2011, 7 (10), e1002331.

[141] Russell, B.; Moss, C.; George, G.; Santaolalla, A.; Cope, A.; Papa, S.; Van Hemelrijck, M. Associations between immune-suppressive and stimulating drugs and novel COVID-19-a systematic review of current evidence. Ecancermedicalscience 2020, 14, 1022i doi: 10.3332/ecancer.2020.1022

[142] Matsuda, S.; Koyasu, S. Mechanisms of Action of Cyclosporine. Immunopharmacology 2000, 47 (2-3), $119-125$.

[143] de Wilde, A. H.; Snijder, E. J.; Kikkert, M.; van Hemert, M. J. Host factors in coronavirus replication. Curr. Top. Microbiol. Immunol.2018, 419, 1-42.

[144] de Wilde, A. H.; Pham, U.; Posthuma, C. C.; Snijder, E. J. Cyclophilins and Cyclophilin inhibitors in nidovirus replication. Virology 2018, 522, 46-55.

[145] Tanaka, Y.; Sato, Y.; Sasaki, T. Suppression of coronavirus replication by cyclophilin inhibitors. Viruses 2013, 5 (5), 1250-1260.

[146] Nagy, P. D.; Wang, R. Y.; Pogany, J.; Hafren, A.; Makinen, K. Emerging Picture of host chaperone and cyclophilin roles in RNA virus replication. Virology 2011, 411 (2), 374-382. 
Repurposing of approved medicine in the management of COVID-19 infection

[147] Yuan, S. Drugs to cure avian influenza infection--multiple ways to prevent cell death. Cell Death Dis. 2013, 4 (10), e835.

[148] Bendickova, K.; Tidu, F.; Fric, J. Calcineurin-NFAT Signalling in Myeloid Leucocytes: New Prospects and pitfalls in immunosuppressive therapy. EMBO Mol. Med. 2017, 9 (8), 990-999.

[149] Hausenloy, D. J.; Boston-Griffiths, E. A.; Yellon, D. M. Cyclosporin A and Cardioprotection: from investigative tool to therapeutic agent. Br. J. Pharmacol. 2012, 165 (5), 1235-1245.

[150] Liddicoat, A. M.; Lavelle, E. C. Modulation of Innate immunity by cyclosporine a. Biochem. Pharmacol. 2019, 163, 472-480.

[151] Campana, C.; Regazzi, M. B.; Buggia, I.; Molinaro, M. clinically significant drug interactions with cyclosporin. an update. Clin. Pharmacokinet. 1996, 30 (2), 141-179.

[152] Kahan, B. D.; Chang, J. Y.; Sehgal, S. N. Preclinical evaluation of a new potent immunosuppressive agent, rapamycin. Transplantation 1991, 52 (2), 185-191.

[153] Sehgal, S. N.; Baker, H.; Vezina, C. Rapamycin (ay-22, 989), a new antifungal antibiotic. J. Antibiot. 1975, 28 (10), 727-732.

[154] Wullschleger, S.; Loewith, R.; Hall, M. N. TOR signaling in growth and metabolism. Cell 2006, 124 (3), 471-484.

[155] Halleck, F.; Duerr, M.; Waiser, J.; Huber, L.; Matz, M.; Brakemeier, S.; Liefeldt, L.; Neumayer, H.-H.; Budde, K. An evaluation of sirolimus in renal transplantation. Expert Opin. Drug Metab. Toxicol. 2012, 8 (10), 1337-1356.

[156] Xie, J.; Wang, X.; Proud, C. G. MTOR inhibitors in cancer therapy. F1000Research 2019, 2016 (5), 2078, doi: 10.12688/f1000research.9207.1

[157] Falzone, L.; Salomone, S.; Libra, M. Evolution of cancer pharmacological treatments at the turn of the third millennium. Front. Pharmacol. 2018, 9, 1300, doi: 10.3389/fphar.2018.01300.

[158] Heitman, J.; Movva, N. R.; Hall, M. N. Targets for cell cycle arrest by the immunosuppressant rapamycin in yeast. Science 1991, 253 (5022), 905-909.

[159] Hay, N.; Sonenberg, N. Upstream and downstream of MTOR. Genes Dev. 2004, 18 (16), 1926-1945.

[160] Zheng, Y.; Li, R.; Liu, S. Immunoregulation with MTOR Inhibitors to Prevent COVID-19 Severity: a novel intervention strategy beyond vaccines and specific antiviral medicines. J. Med. Virol., 2020, 92 (9), 1495-1500.

[161] Raught, B.; Gingras, A. C.; Sonenberg, N. The target of rapamycin (TOR) proteins. Proc. Natl. Acad. Sci. U. S. A. 2001, 98 (13), 7037-7044.

[162] Laplante, M.; Sabatini, D. M. MTOR signaling in growth control and disease. Cell 2012, 149 (2), 274 293.

[163] Liu, S. Q.; Zhao, J. P.; Fan, X. X.; Liu, G. H.; Jiao, H. C.; Wang, X. J.; Sun, S. H.; Lin, H. Rapamycin, a specific inhibitor of the target of rapamycin complex 1, disrupts intestinal barrier integrity in broiler chicks. J. Anim. Physiol. Anim. Nutr. (Berl). 2016, 100 (2), 323-330.

[164] Husain, A.; Byrareddy, S. N. Rapamycin as a potential repurpose drug candidate for the treatment of COVID-19. Chem. Biol. Interact. 2020, 331, 109282.

[165] Routledge, P. A.; Hutchings, A. D. Chapter 9.22 - Therapeutic drug monitoring (TDM); Wild, D. B. T.-T. I. H. (Fourth E., Ed.; Elsevier: Oxford, 2013; pp 945-962.

[166] Conti, P.; Ronconi, G.; Caraffa, A.; Gallenga, C.; Ross, R.; Frydas, I.; Kritas, S. Induction of proinflammatory cytokines (IL-1 and IL-6) and lung inflammation by coronavirus-19 (COVID-19 or SARSCoV-2): Anti-inflammatory strategies. J. Biol. Regulat. Homeostat. Agent. 2020, 34 (2), 327-331.

[167] Coquillard, C.; Vilchez, V.; Marti, F.; Gedaly, R. MTOR signaling in regulatory t cell differentiation and expansion. SOJ Immunol. 2015, 3 (1). 1-10. doi: http://dx.doi.org/10.15226/soji/3/1/00122

[168] Huang, N.; Perl, A. Metabolism as a target for modulation in autoimmune diseases. Trends Immunol. 2018, $39(7), 562-576$.

[169] Weichhart, T.; Hengstschläger, M.; Linke, M. Regulation of Innate immune cell function by mtor. Nat. Rev. Immunol. 2015, 15 (10), 599-614.

[170] Lai, Z.-W.; Hanczko, R.; Bonilla, E.; Caza, T. N.; Clair, B.; Bartos, A.; Miklossy, G.; Jimah, J.; Doherty, E.; Tily, H.; et al. N-Acetylcysteine reduces disease activity by blocking mammalian target of rapamycin in t cells from systemic lupus erythematosus patients: a randomized, double-blind, placebo-controlled trial. Arthritis Rheum. 2012, 64 (9), 2937-2946.

[171] Raybuck, A. L.; Cho, S. H.; Li, J.; Rogers, M. C.; Lee, K.; Williams, C. L.; Shlomchik, M.; Thomas, J. W.; Chen, J.; Williams, J. V; et al. B Cell-intrinsic MTORC1 promotes germinal center-defining transcription factor gene expression, somatic hypermutation, and memory B cell generation in humoral immunity. J. Immunol. 2018, 200 (8), 2627-2639. 
[172] Kay, J. E.; Kromwel, L.; Doe, S. E.; Denyer, M. Inhibition of T and B lymphocyte proliferation by rapamycin. Immunology 1991, 72 (4), 544-549.

[173] Wicker, L. S.; Boltz, R. C. J.; Matt, V.; Nichols, E. A.; Peterson, L. B.; Sigal, N. H. Suppression of B cell activation by cyclosporin a, FK506 and rapamycin. Eur. J. Immunol. 1990, 20 (10), 2277-2283.

[174] Ye, L.; Lee, J.; Xu, L.; Mohammed, A.-U.-R.; Li, W.; Hale, J. S.; Tan, W. G.; Wu, T.; Davis, C. W.; Ahmed, R.; et al. MTOR promotes antiviral humoral immunity by differentially regulating CD4 Helper T cell and B cell responses. J. Virol. 2017, 91(4), e01653.

[175] Limon, J. J.; So, L.; Jellbauer, S.; Chiu, H.; Corado, J.; Sykes, S. M.; Raffatellu, M.; Fruman, D. A. MTOR kinase inhibitors promote antibody class switching via MTORC2 inhibition. Proc. Natl. Acad. Sci. U.S. A. 2014, 111 (47), E5076-5085.

[176] Song, P.; Li, W.; Xie, J.; Hou, Y.; You, C. Cytokine storm induced by SARS-CoV-2. Clin. Chim. Acta. 2020, 509, 280-287.

[177] Diao, B.; Wang, C.; Tan, Y.; Chen, X.; Liu, Y.; Ning, L.; Chen, L.; Li, M.; Liu, Y.; Wang, G.; et al. Reduction and functional exhaustion of t cells in patients with coronavirus disease 2019 (COVID-19). Front. Immunol. 2020, 11, 827, doi: 10.3389/fimmu.2020.00827.

[178] Jia, X.; Liu, B.; Bao, L.; Lv, Q.; Li, F.; Li, H.; An, Y.; Zhang, X.; Cao, B.; Wang, C. Delayed oseltamivir plus sirolimus treatment attenuates $\mathrm{h} 1 \mathrm{n} 1$ virus-induced severe lung injury correlated with repressed nlrp3 inflammasome activation and inflammatory cell infiltration. PLoS Pathog. 2018, 14 (11), e1007428.

[179] Wang, C.-H.; Chung, F.-T.; Lin, S.-M.; Huang, S.-Y.; Chou, C.-L.; Lee, K.-Y.; Lin, T.-Y.; Kuo, H.-P. Adjuvant Treatment with a mammalian target of rapamycin inhibitor, sirolimus, and steroids improves outcomes in patients with severe H1N1 pneumonia and acute respiratory failure. Crit. Care Med. 2014, 42 (2), 313-321.

[180] Yang, M. Cell Pyroptosis, a potential pathogenic mechanism of 2019-NCoV infection. SSRN Electron. J. 2020. doi:10.2139/ssrn.3527420.

[181] Zhou, Y.; Hou, Y.; Shen, J.; Huang, Y.; Martin, W.; Cheng, F. Network-based drug repurposing for novel coronavirus 2019-NCoV/SARS-CoV-2. Cell Discov. 2020, 6, 14. doi:10.1038/s41421-020-0153-3

[182] Rubbert-Roth, A.; Furst, D. E.; Nebesky, J. M.; Jin, A.; Berber, E. A review of recent advances using tocilizumab in the treatment of rheumatic diseases. Rheumatol. Ther. 2018, 5 (1), 21-42.

[183] Jiménez Morales, A.; Maldonado-Montoro, M.; Martínez de la Plata, J. E.; Pérez Ramírez, C.; Daddaoua, A.; Alarcón Payer, C.; Expósito Ruiz, M.; García Collado, C. FCGR2A/FCGR3A gene polymorphisms and clinical variables as predictors of response to tocilizumab and rituximab in patients with rheumatoid arthritis. J. Clin. Pharmacol. 2019, 59 (4), 517-531.

[184] Maldonado-Montoro, M.; Cañadas-Garre, M.; González-Utrilla, A.; Ángel Calleja-Hernández, M. Influence of IL6R gene polymorphisms in the effectiveness to treatment with tocilizumab in rheumatoid arthritis. Pharmacogenomics J. 2018, 18 (1), 167-172.

[185] Maldonado-Montoro, M.; Cañadas-Garre, M.; González-Utrilla, A.; Plaza-Plaza, J. C.; Calleja-Hernández, M. Y. Genetic and clinical biomarkers of tocilizumab response in patients with rheumatoid arthritis. Pharmacol. Res. 2016, 111, 264-271.

[186] Navarro, G.; Taroumian, S.; Barroso, N.; Duan, L.; Furst, D. Tocilizumab in rheumatoid arthritis: a metaanalysis of efficacy and selected clinical conundrums. Semin. Arthritis Rheum. 2014, 43 (4), 458-469.

[187] Yokota, S.; Miyamae, T.; Imagawa, T.; Iwata, N.; Katakura, S.; Mori, M.; Woo, P.; Nishimoto, N.; Yoshizaki, K.; Kishimoto, T. Therapeutic efficacy of humanized recombinant anti-interleukin-6 receptor antibody in children with systemic-onset juvenile idiopathic arthritis. Arthritis Rheum. 2005, 52 (3), 818 825 .

[188] Grupp, S. A.; Kalos, M.; Barrett, D.; Aplenc, R.; Porter, D. L.; Rheingold, S. R.; Teachey, D. T.; Chew, A.; Hauck, B.; Wright, J. F.; et al. Chimeric antigen receptor-modified T Cells for acute lymphoid leukemia. N. Engl. J. Med. 2013, 368 (16), 1509-1518.

[189] Winkler, U.; Jensen, M.; Manzke, O.; Schulz, H.; Diehl, V.; Engert, A. Cytokine-Release syndrome in patients with b-cell chronic lymphocytic leukemia and high lymphocyte counts after treatment with an anti-CD20 monoclonal antibody (Rituximab, IDEC-C2B8). Blood 1999, 94 (7), 2217-2224.

[190] Zhang, C.; Wu, Z.; Li, J.-W.; Zhao, H.; Wang, G.-Q. Cytokine release syndrome in severe COVID-19: interleukin-6 receptor antagonist tocilizumab may be the key to reduce mortality. Int. J. Antimicrob. Agent. 2020, 55 (5), 105954.

[191] Xu, X.; Han, M.; Li, T.; Sun, W.; Wang, D.; Fu, B.; Zhou, Y.; Zheng, X.; Yang, Y.; Li, X.; et al. Effective treatment of severe covid-19 patients with tocilizumab. Proc. Natl. Acad. Sci. U. S. A. 2020, 117 (20), 10970-10975.

[192] Morrison, A. R.; Johnson, J. M.; Griebe, K. M.; Jones, M. C.; Stine, J. J.; Hencken, L. N.; To, L.; Bianchini, M. L.; Vahia, A. T.; Swiderek, J.; et al. Clinical characteristics and predictors of survival in adults with coronavirus disease 2019 receiving tocilizumab. J. Autoimmun. 2020, 114, 102512. 
Repurposing of approved medicine in the management of COVID-19 infection

[193] Gupta, S.; Wang, W.; Hayek, S. S.; Chan, L.; Mathews, K. S.; Melamed, M. L.; Brenner, S. K.; LeonbergYoo, A.; Schenck, E. J.; Radbel, J.; et al. Association between early treatment with tocilizumab and mortality among critically ill patients with COVID-19. JAMA Intern. Med. 2021, 181 (1), 41-51.

[194] Rosas, I. O.; Bräu, N.; Waters, M.; Go, R.; Hunter, B. D.; Bhagani, S.; Skiest, D.; Aziz, M. S.; Cooper, N.; Douglas, I. S.; et al. Tocilizumab in hospitalized patients with COVID-19 pneumonia. medRxiv, 2020, 2020.08.27.20183442.

[195] Salvarani, C.; Dolci, G.; Massari, M.; Merlo, D. F.; Cavuto, S.; Savoldi, L.; Bruzzi, P.; Boni, F.; Braglia, L.; Turrà, C.; et al. Effect of tocilizumab vs standard care on clinical worsening in patients hospitalized with covid-19 pneumonia: a randomized clinical trial. JAMA Intern. Med. 2021, 181 (1), 24-31.

[196] Hermine, O.; Mariette, X.; Tharaux, P.-L.; Resche-Rigon, M.; Porcher, R.; Ravaud, P.; Group, C.-19 C. Effect of tocilizumab vs usual care in adults hospitalized with COVID-19 and moderate or severe pneumonia: a randomized clinical trial. JAMA Intern. Med. 2021, 181 (1), 32-40.

[197] Stone, J. H.; Frigault, M. J.; Serling-Boyd, N. J.; Fernandes, A. D.; Harvey, L.; Foulkes, A. S.; Horick, N. K.; Healy, B. C.; Shah, R.; Bensaci, A. M.; et al. Efficacy of tocilizumab in patients hospitalized with Covid-19. N. Engl. J. Med., 2020, 383 (24), 2333-2344.

[198] Luo, P.; Liu, Y.; Qiu, L.; Liu, X.; Liu, D.; Li, J. Tocilizumab Treatment in COVID-19: A Single Center Experience. J. Med. Virol. 2020, 92 (7), 814-818.

[199] Cellina, M.; Orsi, M.; Bombaci, F.; Sala, M.; Marino, P.; Oliva, G. Favorable changes of CT findings in a patient with COVID-19 pneumonia after treatment with tocilizumab. Diagn. Interv. Imaging. 2020, 101 (5), 323-324.

[200] Michot, J.-M.; Albiges, L.; Chaput, N.; Saada, V.; Pommeret, F.; Griscelli, F.; Balleyguier, C.; Besse, B.; Marabelle, A.; Netzer, F.; et al. Tocilizumab, an anti-il-6 receptor antibody, to treat covid-19-related respiratory failure: a case report. Ann. Oncol. 2020, 31 (7), 961-964.

[201] Zhang, X.; Song, K.; Tong, F.; Fei, M.; Guo, H.; Lu, Z.; Wang, J.; Zheng, C. First case of COVID-19 in a patient with multiple myeloma successfully treated with tocilizumab. Blood Adv., 2020, 4 (7), 1307-1310.

[202] Antwi-Amoabeng, D.; Kanji, Z.; Ford, B.; Beutler, B. D.; Riddle, M. S.; Siddiqui, F. Clinical outcomes in COVID-19 patients treated with tocilizumab: an individual patient data systematic review. J. Med. Virol. 2020, 92 (11), 2516-2522.

[203] Capra, R.; De Rossi, N.; Mattioli, F.; Romanelli, G.; Scarpazza, C.; Sormani, M. P.; Cossi, S. Impact of low dose tocilizumab on mortality rate in patients with COVID-19 related pneumonia. Eur. J. Intern. Med. 2020, 76, 31-35.

[204] Sciascia, S.; Aprà, F.; Baffa, A.; Baldovino, S.; Boaro, D.; Boero, R.; Bonora, S.; Calcagno, A.; Cecchi, I.; Cinnirella, G.; et al. Pilot prospective open, single-arm multicentre study on off-label use of tocilizumab in patients with severe COVID-19. Clin. Exp. Rheumatol. 2020, 38 (3), 529-532.

[205] Klopfenstein, T.; Zayet, S.; Lohse, A.; Balblanc, J.-C.; Badie, J.; Royer, P.-Y.; Toko, L.; Mezher, C.; Kadiane-Oussou, N. J.; Bossert, M.; et al. Tocilizumab Therapy reduced intensive care unit admissions and/or mortality in COVID-19 patients. Med. Mal. Infect., 2020, 50 (5), 397-400.

[206] Kevzara, INN-Sarilumab - Product Information European Medicines Agency. https://www.ema.europa.eu/en/documents/product-information/kevzara-epar-productinformation_en.pdf

[207] Lim, Y. X.; Ng, Y. L.; Tam, J. P.; Liu, D. X. Human coronaviruses: a review of virus-host interactions. Diseases 2016, 4 (3), 26, doi: 10.3390/diseases4030026.

[208] Wang, L.; Wang, Y.; Ye, D.; Liu, Q. Review of the 2019 novel coronavirus (SARS-CoV-2) based on current evidence. Int. J. Antimicrob. Agent., 2020, 55 (6), 105948.

[209] Petrosillo, N.; Viceconte, G.; Ergonul, O.; Ippolito, G.; Petersen, E. COVID-19, SARS and MERS: are they closely related? Clin. Microbiol. Infect. 2020, 26 (6), 729-734.

[210] Zaim, S.; Chong, J. H.; Sankaranarayanan, V.; Harky, A. COVID-19 and Multiorgan Response. Curr. Probl. Cardiol. 2020, 45 (8), 100618.

[211] Raimondo, M. G.; Biggioggero, M.; Crotti, C.; Becciolini, A.; Favalli, E. G. Profile of sarilumab and its potential in the treatment of rheumatoid arthritis. Drug Des. Devel. Ther. 2017, 11, 1593-1603.

[212] Hirano, T.; Murakami, M. COVID-19: A new virus, but a familiar receptor and cytokine release syndrome. Immunity, 2020, 52 (5), 731-733.

[213] Della-Torre, E.; Campochiaro, C.; Cavalli, G.; De Luca, G.; Napolitano, A.; La Marca, S.; Boffini, N.; Da Prat, V.; Di Terlizzi, G.; Lanzillotta, M.; et al. Interleukin-6 blockade with sarilumab in severe COVID19 pneumonia with systemic hyperinflammation: an open-label cohort study. Ann. Rheum. Dis. 2020, 79 (10), 1277 LP -1285 . 
Patel et al., Org. Commun. (2022) 15:1 1-31

[214] Gremese, E.; Cingolani, A.; Bosello, S. L.; Alivernini, S.; Tolusso, B.; Perniola, S.; Landi, F.; Pompili, M.; Murri, R.; Santoliquido, A.; et al. Sarilumab use in severe SARS-CoV-2 pneumonia. EClinicalMedicine 2020, 27, 100553.

[215] Sarilumab COVID-19 Clinical Trial. https://clinicaltrials.gov/ct2/show/NCT04327388

[216] Strand, V.; Reaney, M.; Chen, C.-I.; Proudfoot, C. W. J.; Guillonneau, S.; Bauer, D.; Mangan, E.; Graham, N. M. H.; van Hoogstraten, H.; Lin, Y.; et al. Sarilumab improves patient-reported outcomes in rheumatoid arthritis patients with inadequate response/intolerance to tumour necrosis factor inhibitors. RMD open, 2017, 3 (1), e000416.

[217] Rossignol, J.-F. Nitazoxanide: a first-in-class broad-spectrum antiviral agent. Antiviral Res. 2014, 110, 94-103.

[218] Stachulski, A. V.; Santoro, M. G.; Piacentini, S.; Belardo, G.; Frazia, S. La; Pidathala, C.; Row, E. C.; Berry, N. G.; Iqbal, M.; Allman, S. A.; et al. Second-generation nitazoxanide derivatives: thiazolides are effective inhibitors of the influenza a virus. Future Med. Chem. 2018, 10 (8), 851-862.

[219] Kelleni, M. T. Nitazoxanide/azithromycin combination for COVID-19: a suggested new protocol for early management. Pharmacol. Res. 2020, 157,104874.

[220] Singh, N.; Narayan, S. Nitazoxanide : a broad spectrum antimicrobial. Med. J. Armed Force. Ind. 2011, $67(1), 67-68$.

[221] Rossignol, J.-F. Nitazoxanide, a new drug candidate for the treatment of middle east respiratory syndrome coronavirus. J. Infect. Public Health 2016, 9 (3), 227-230.

[222] Cao, J.; Forrest, J. C.; Zhang, X. A Screen of the NIH clinical collection small molecule library identifies potential anti-coronavirus drugs. Antiviral Res. 2015, 114, 1-10.

[223] Hill, A.; Wang, J.; Levi, J.; Heath, K.; Fortunak, J. Minimum costs to manufacture new treatments for COVID-19. J. Virus Erad. 2020, 6 (2) 61-69.

[224] Jasenosky, L. D.; Cadena, C.; Mire, C. E.; Borisevich, V.; Haridas, V.; Ranjbar, S.; Nambu, A.; Bavari, S.; Soloveva, V.; Sadukhan, S.; et al. The FDA-approved oral drug nitazoxanide amplifies host antiviral responses and inhibits ebola virus. iScience 2019, 19, 1279-1290.

[225] Martins-Filho, P. R.; Barreto-Alves, J. A.; Fakhouri, R. Potential role for nitazoxanide in treating SARSCoV-2 infection. Am. J. Physiol. Lung Cell. Mol. Physiol. 2020319 (1), L35-L36.

[226] Shakya, A.; Bhat, H. R.; Ghosh, S. K. Update on nitazoxanide: a multifunctional chemotherapeutic Agent. Curr. Drug Discov. Technol. 2018, 15 (3), 201-213.

[227] Choy, K.-T.; Wong, A. Y.-L.; Kaewpreedee, P.; Sia, S. F.; Chen, D.; Hui, K. P. Y.; Chu, D. K. W.; Chan, M. C. W.; Cheung, P. P.-H.; Huang, X.; et al. Remdesivir, lopinavir, emetine, and homoharringtonine inhibit SARS-CoV-2 replication in vitro. Antiviral Res. 2020, 178, 104786.

[228] Mahmoud, D. B.; Shitu, Z.; Mostafa, A. Drug repurposing of nitazoxanide: can it be an effective therapy for COVID-19? J. Genet. Eng. Biotechnol. 2020, 18 (1), 35.

[229] Negishi, H.; Taniguchi, T.; Yanai, H. The Interferon (IFN) Class of cytokines and the ifn regulatory factor (IRF) transcription factor family. Cold Spring Harb. Perspect. Biol. 2018, 10 (11), a028423.

[230] Schoggins, J. W. Interferon-stimulated genes: what do they all do? Annu. Rev. Virol. 2019, 6 (1), 567584.

[231] Pestka, S.; Krause, C. D.; Walter, M. R. Interferons, interferon-like cytokines, and their receptors. Immunol. Rev. 2004, 202, 8-32.

[232] Sun, W.; Li, Y.; Chen, L.; Chen, H.; You, F.; Zhou, X.; Zhou, Y.; Zhai, Z.; Chen, D.; Jiang, Z. ERIS, an endoplasmic reticulum IFN stimulator, activates innate immune signaling through dimerization. Proc. Natl. Acad. Sci. U. S. A., 2009, 106 (21), 8653-8658.

[233] Kotenko, S. V; Gallagher, G.; Baurin, V. V; Lewis-Antes, A.; Shen, M.; Shah, N. K.; Langer, J. A.; Sheikh, F.; Dickensheets, H.; Donnelly, R. P. IFN-lambdas mediate antiviral protection through a distinct class II cytokine receptor complex. Nat. Immunol. 2003, 4 (1), 69-77.

[234] Sheppard, P.; Kindsvogel, W.; Xu, W.; Henderson, K.; Schlutsmeyer, S.; Whitmore, T. E.; Kuestner, R.; Garrigues, U.; Birks, C.; Roraback, J.; et al. IL-28, IL-29 and their class II cytokine receptor IL-28R. Nat. Immunol., 2003, 4 (1), 63-68.

[235] Prokunina-Olsson, L.; Muchmore, B.; Tang, W.; Pfeiffer, R. M.; Park, H.; Dickensheets, H.; Hergott, D.; Porter-Gill, P.; Mumy, A.; Kohaar, I.; et al. A Variant upstream of IFNL3 (IL28B) creating a new interferon gene IFNL4 Is associated with impaired clearance of hepatitis c virus. Nat. Genet. 2013, 45 (2), 164-171.

[236] Bhimraj, A.; Morgan, R. L.; Shumaker, A. H.; Lavergne, V.; Baden, L.; Cheng, V. C.-C.; Edwards, K. M.; Gandhi, R.; Muller, W. J.; O’Horo, J. C.; et al. Infectious diseases society of America guidelines on the treatment and management of patients with coronavirus disease 2019 (COVID-19). Clin. Infect. Dis. 2020, ciaa478. doi: 10.1093/cid/ciaa478. 
Repurposing of approved medicine in the management of COVID-19 infection

[237] Siddiqi, H. K.; Mehra, M. R. COVID-19 illness in native and immunosuppressed states: a clinicaltherapeutic staging proposal. J. Heart Lung Transplant. 2020, 39(5), 405-407.

[238] Zhou, F.; Yu, T.; Du, R.; Fan, G.; Liu, Y.; Liu, Z.; Xiang, J.; Wang, Y.; Song, B.; Gu, X.; et al. clinical course and risk factors for mortality of adult inpatients with COVID-19 in Wuhan, China: a retrospective cohort study. Lancet, 2020, 395 (10229), 1054-1062.

[239] Blanco-Melo, D.; Nilsson-Payant, B. E.; Liu, W.-C.; Uhl, S.; Hoagland, D.; Møller, R.; Jordan, T. X.; Oishi, K.; Panis, M.; Sachs, D.; et al. Imbalanced host response to sars-cov-2 drives development of COVID-19. Cell 2020, 181 (5), 1036-1045.e9.

[240] Hadjadj, J.; Yatim, N.; Barnabei, L.; Corneau, A.; Boussier, J.; Smith, N.; Péré, H.; Charbit, B.; Bondet, V.; Chenevier-Gobeaux, C.; et al. Impaired type I interferon activity and inflammatory responses in severe COVID-19 Patients. Science 2020, 369 (6504), 718-724.

[241] Song, Y.; Zhang, M.; Yin, L.; Wang, K.; Zhou, Y.; Zhou, M.; Lu, Y. COVID-19 treatment: close to a cure? a rapid review of pharmacotherapies for the novel coronavirus (SARS-CoV-2). Int. J. Antimicrob. Agent. 2020, 56 (2), 106080.

[242] Sallard, E.; Lescure, F.-X.; Yazdanpanah, Y.; Mentre, F.; Peiffer-Smadja, N. Type 1 Interferons as a potential treatment against COVID-19. Antiviral Res. 2020, 178, 104791.

[243] Meng, Z.; Wang, T.; Chen, L.; Chen, X.; Li, L.; Qin, X.; Li, H.; Luo, J. An experimental trial of recombinant human interferon alpha nasal drops to prevent covid-19 in medical staff in an epidemic area. medRxiv, 2020, 2020.04.11.20061473.

[244] O’Brien, T. R.; Thomas, D. L.; Jackson, S. S.; Prokunina-Olsson, L.; Donnelly, R. P.; Hartmann, R. Weak Induction of interferon expression by severe acute respiratory syndrome coronavirus 2 supports clinical trials of interferon- $\lambda$ to treat early coronavirus disease 2019. Clin. Infect. Dis. 2020, 71 (6), 1410-1412.

[245] Arab-Zozani, M.; Hassanipour, S.; Ghoddoosi-Nejad, D. Favipiravir for Treating patients with novel coronavirus (COVID-19): protocol for a systematic review and meta-analysis of randomised clinical trials. BMJ Open, 2020, 10 (7), e039730.

[246] Furuta, Y.; Takahashi, K.; Fukuda, Y.; Kuno, M.; Kamiyama, T.; Kozaki, K.; Nomura, N.; Egawa, H.; Minami, S.; Watanabe, Y.; et al. In vitro and in vivo activities of anti-influenza virus compound T-705. Antimicrob. Agents Chemother. 2002, 46 (4), 977-981.

[247] Dong, L.; Hu, S.; Gao, J. Discovering drugs to treat coronavirus disease 2019 (COVID-19). Drug Discov. Ther. 2020, 14 (1), 58-60.

[248] Furuta, Y.; Komeno, T.; Nakamura, T. Favipiravir (T-705), a Broad spectrum inhibitor of viral rna polymerase. Proc. Jpn. Acad. Ser. B. Phys. Biol. Sci. 2017, 93 (7), 449-463.

[249] Gowen, B. B.; Wong, M.-H.; Jung, K.-H.; Sanders, A. B.; Mendenhall, M.; Bailey, K. W.; Furuta, Y.; Sidwell, R. W. In vitro and in vivo activities of t-705 against arenavirus and bunyavirus infections. Antimicrob. Agents Chemother. 2007, 51 (9), 3168-3176.

[250] Rocha-Pereira, J.; Jochmans, D.; Dallmeier, K.; Leyssen, P.; Nascimento, M. S. J.; Neyts, J. Favipiravir (T-705) inhibits in vitro norovirus replication. Biochem. Biophys. Res. Commun. 2012, 424 (4), 777-780.

[251] Holshue, M. L.; DeBolt, C.; Lindquist, S.; Lofy, K. H.; Wiesman, J.; Bruce, H.; Spitters, C.; Ericson, K.; Wilkerson, S.; Tural, A.; et al. First case of 2019 novel coronavirus in the united states. N. Engl. J. Med. 2020, 382 (10), 929-936.

[252] Baranovich, T.; Wong, S.-S.; Armstrong, J.; Marjuki, H.; Webby, R. J.; Webster, R. G.; Govorkova, E. A. T-705 (Favipiravir) Induces lethal mutagenesis in influenza a h1n1 viruses in vitro. J. Virol. 2013, 87 (7), 3741-3751.

[253] Jin, Z.; Smith, L. K.; Rajwanshi, V. K.; Kim, B.; Deval, J. The ambiguous base-pairing and high substrate efficiency of T-705 (Favipiravir) Ribofuranosyl 5'-triphosphate towards influenza a virus polymerase. PLoS One 2013, 8 (7), e68347.

[254] Agrawal, U.; Raju, R.; Udwadia, Z. F. Favipiravir: a new and emerging antiviral option in COVID-19. Med. J. Armed Force Ind. 2020, 76 (4), 370-376.

[255] Doi, Y.; Hibino, M.; Hase, R.; Yamamoto, M.; Kasamatsu, Y.; Hirose, M.; Mutoh, Y.; Homma, Y.; Terada, M.; Ogawa, T.; et al. A prospective, randomized, open-label trial of early versus late favipiravir therapy in hospitalized patients with COVID-19. Antimicrob. Agents Chemother. 2020, 64 (12), e01897-20

[256] Painter, W. P.; Holman, W.; Bush, J. A.; Almazedi, F.; Malik, H.; Eraut, N. C. J. E.; Morin, M. J.; Szewczyk, L. J.; Painter, G. R. Human safety, tolerability, and pharmacokinetics of molnupiravir, a novel broad-spectrum oral antiviral agent with activity against SARS-CoV-2. Antimicrob. Agents Chemother. 2021, 65 (5), e02428-20.

[257] Toots, M.; Yoon, J.-J.; Cox, R. M.; Hart, M.; Sticher, Z. M.; Makhsous, N.; Plesker, R.; Barrena, A. H.; Reddy, P. G.; Mitchell, D. G.; et al. Characterization of orally efficacious influenza drug with high resistance barrier in ferrets and human airway epithelia. Sci. Transl. Med. 2019, 11(515), eaax5866. 
Patel et al., Org. Commun. (2022) 15:1 1-31

[258] Agostini, M. L.; Pruijssers, A. J.; Chappell, J. D.; Gribble, J.; Lu, X.; Andres, E. L.; Bluemling, G. R.; Lockwood, M. A.; Sheahan, T. P.; Sims, A. C.; et al. Small-molecule antiviral $\beta$-d-n (4)-hydroxycytidine inhibits a proofreading-intact coronavirus with a high genetic barrier to resistance. J. Virol. 2019, 93 (24), e01348-19.

[259] Kabinger, F.; Stiller, C.; Schmitzová, J.; Dienemann, C.; Kokic, G.; Hillen, H. S.; Höbartner, C.; Cramer, P. Mechanism of molnupiravir-induced sars-cov-2 mutagenesis. Nat. Struct. Mol. Biol. 2021, 28 (9), 740746.

[260] Robson, F.; Khan, K. S.; Le, T. K.; Paris, C.; Demirbag, S.; Barfuss, P.; Rocchi, P.; Ng, W.-L. Coronavirus RNA proofreading: molecular basis and therapeutic targeting. Mol. Cell, 2020, 79 (5), 710-727.

[261] Dyer, O. Covid-19: FDA expert panel recommends authorising molnupiravir but also voices concerns. BMJ 2021, 375, n2984.

[262] Mahase, E. Covid-19: Molnupiravir reduces risk of hospital admission or death by $50 \%$ in patients at risk, MSD reports. BMJ 2021, 375, n2422.

[263] Zhao, J.; Guo, S.; Yi, D.; Li, Q.; Ma, L.; Zhang, Y.; Wang, J.; Li, X.; Guo, F.; Lin, R.; et al. A cell-based assay to discover inhibitors of SARS-CoV-2 RNA dependent RNA polymerase. Antiviral Res. 2021, 190, 105078.

[264] Finbloom, D. S.; Silver, K.; Newsome, D. A.; Gunkel, R. Comparison of hydroxychloroquine and chloroquine use and the development of retinal toxicity. J. Rheumatol. 1985, 12 (4), 692-694.

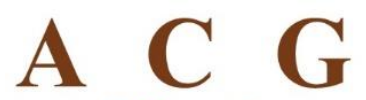

publications

(C) 2022 ACG Publications 